\title{
A Study on the Improvement of Double-Skin Facade Operation for Reducing Heating Load in Winter
}

\author{
Uk-Joo Sung ${ }^{1}$ and Seok-Hyun Kim ${ }^{2, *}$ \\ 1 Center for Climatic Environment Real-scale Testing, Korea Conformity Laboratories, Jincheon 27872, Korea; \\ suj21c@kcl.re.kr \\ 2 Energy ICT·ESS Laboratory, Korea Institute of Energy Research, Daejeon 34101, Korea \\ * Correspondence: ksh7000@kier.re.kr
}

Received: 29 September 2019; Accepted: 28 October 2019; Published: 7 November 2019

check for updates

\begin{abstract}
A double-skin facade makes it possible to gain irradiance through the glass on the outer side in summer, and to increase the temperature of air flowing in the cavity so as to induce the flow of air current. Therefore, a double-skin facade is able to reduce the load of the outer skin, which is delivered from the outside to the inside in summer, and to serve as a buffer space for the internal and external environments in winter, and thereby prevent heat loss from the building envelope. Theoretical analysis was conducted to review the heat effects of a double-skin facade and to evaluate the performance of a plan for indoor load reduction. This study carried out a field measurement of a building with a double-skin facade and then analyzed the thermal phenomenon occurring in between the outer skin of the outside and the skin of the inside facing the building surface, according to the effects of irradiance going into the double-skin facade cavity. In order to propose an indoor air conditioning energy reduction plan using preheated air through the double-skin facade, this study utilized a building simulation to be implemented on the target building and then analyzed the effects of the improvement plan for the double-skin facade. A simulation model was suggested that implemented the aforementioned airflow network and analyzed the ventilation performance and energy performance according to the application of alternative plans and thermal effect. To find the actual state of operation of the double-skin facade in winter, this study measured the target building. A solar chimney-based double-skin facade was analyzed in winter. As a result, with the application of a solar chimney and a rise in its height, the available capacity of relatively larger solar heat increased, and therefore the proposed plan had excellent performance in terms of heating energy saving. When the thermal effect was applied to the solar chimney, the heating energy use effect of the solar irradiance of the double-skin facade was larger. When thermal effect was applied to a three-floor solar chimney, the heating energy use increased to about 7.6 times higher than that of the original performance of the double-skin facade.
\end{abstract}

Keywords: double skin facade; ventilation; heating load; solar chimney; Energy Simulation

\section{Introduction}

In order to save heating energy in a building in winter, passive techniques for enhancing building insulation can be applied. In particular, a double-skin facade makes it possible to gain irradiance through the glass on the outer side in summer, and to increase the temperature of air flowing in the cavity so as to induce the flow of air current. Therefore, a double-skin facade is able to reduce the load of the outer skin, which is delivered from the outside to the inside in summer, and to serve as a buffer space for the internal and external environments in winter [1,2], and thereby to prevent heat loss from the building envelope. To verify the effects of double-skin facades with multiple functions, there are 
many studies focusing on various aspects. By analysis of the results, the energy saving effects have been verified.

Research on the evaluation of double-skin facade applicability draws its conclusions through testing and simulation. Generally, results drawn from tests are used as a verification tool to secure the validity of a simulation model. Stec et al. analyzed the effects of double-skin facades on air conditioning systems $[3,4]$. With the use of the SimulinkTM program, they analyzed the performance of air conditioning systems in terms of whether or not to apply a double-skin facade, the application of blinds, and control. Based on the measurement results of the test cell applied to a real building, they proved the validity of their analysis model in comparison. In addition, these researchers proposed a simulation model in which plants are applied to a double-skin facade cavity, established the test facility to verify the proposed model, and proved the simulation model on the basis of the test results. As a result, the research concluded that a double-skin facade whose cavity had plants improved the comfort and energy saving of the internal environment of building. There has been research to quantitatively evaluate the energy of irradiance going through double-skin facades and to effectively analyze heat transfer in consideration of radiative heat transfer. In the case of double-skin facades, the SHGC (solar heat gain coefficient) of the total system, which includes the outer skin of the internal side along with the transparent outer skin with solar heat transmittance, is a main indication needed to judge the optical performance of the building envelope, just as the window and door with a general outer skin of transmittance. Chou et al. established the SHGC calculation test system based on the Hot Box method in order to analyze the influence of double-skin facades in terms of the energy management of buildings, and then calculated the SHGC of each azimuthal angle of the installation of a double-skin facade [5]. In addition, these researchers analyzed the correlation between the WWR (Window to Wall Ratio) of the inner wall of a double-skin facade and the ETTV (Envelope Thermal Transfer Value), the heat performance judgment indication of the outer skin according to the SHGC of the whole outer skin.

In order to find the effects of double-skin facades in winter, Lei $\mathrm{Xu}$ et al. utilized the double-skin facade of a two-floor residential building and analyzed the cooling effect through ventilation in summer, the greenhouse effect in winter, and the internal environment through the natural air conditioning effect and energy saving in the intermediate period [6]. Their field test showed that the cooling load reduced by about $10-15 \%$ thanks to natural ventilation in summer, and the cooling load reduced by $20 \%$ and lower in winter. Simulation-based research was conducted to optimize the system of a double-skin facade. Elisabeth Gratia et al. evaluated a variety of options by utilizing the multistory double-skin facade of the building suggested in IES (Illuminating Engineering Society) TASK 27 'Performance of solar facade components' [7-13]. A typical applicability evaluation item was the performance of the natural ventilation that occurred in the double-skin facade cavity. These researchers analyzed the performance of the ventilation of the double-skin facade in the daytime and nighttime according to installation direction, wind direction, and wind velocity. In addition, they evaluated applicability differently depending on what type of double-skin facade was selected out of eight different types, and thereby drew the optimal design plan of the double-skin facade to be installed in the south side and compared the cooling and heating energy consumption. As a result, they suggested the possibility of inefficient operation, which means that if the natural ventilation of the double-skin facade cavity during a cooling period is not active, the application effect can be lowered. In addition, in order to analyze the greenhouse effect of the double-skin facade, they drew passive design factors and thereby looked into the temperature distribution of the double-skin facade cavity. The design factors of the double-skin facade were the external environment and components of the double-skin facade, including the intensity of inflow irradiance, external wind direction and wind velocity, azimuthal angle of the installation of the double-skin facade, awning apparatus and its color, width of the cavity, inlet and outlet areas of ventilation [14,15], and window-to-wall ratio and window type of the inner skin. The temperature concentration problem of the double-skin facade cavity in summer by inefficient operation was able to be solved by improvement plans, such as appropriate inlet and outlet areas of 
ventilation, an appropriate size of cavity, and an appropriate position of the awning apparatus. All of the previous studies used the Tas building energy analysis simulation program of the EDSL company so as to draw results.

Based on the results of the previous studies, this research tries to suggest an improvement plan for double-skin facade operation in order to save indoor load in winter. More specifically, it tries to analyze the current operation state of a double-skin facade in winter through the field measurement of a double-skin facade installed in a real building, to propose an improvement plan, and to verify the proposed plan. Figure 1 illustrates the flow chart of this research.

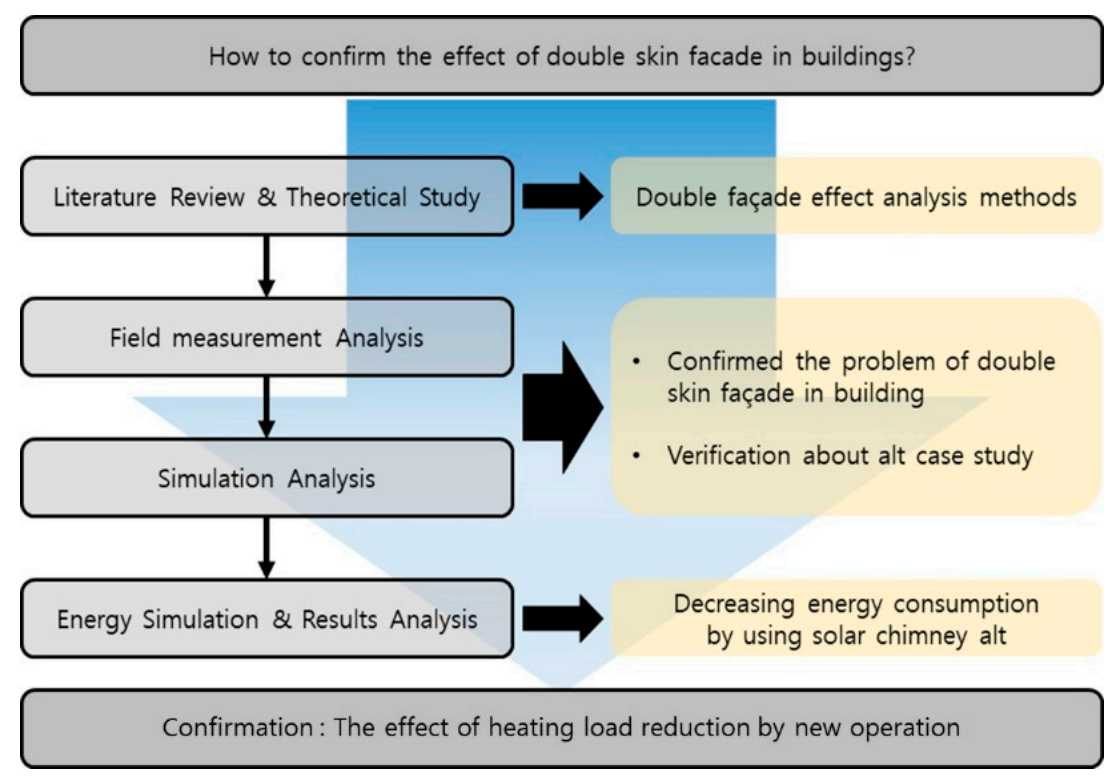

Figure 1. Research method.

\section{Theory of Double-Skin Facade Performance Evaluation}

Theoretical analysis was conducted to review the heat effects of double-skin facades and to evaluate the performance of the plan for indoor load reduction. This study reviewed the basic theories of heat transfer and airflow network models, which were applied to evaluate an improvement plan.

\subsection{Analysis of the Basic Theory of Double-Skin Facade Heat Transfer}

In a double-skin facade, fluid flow occurs in the vertical direction of the cavity. Since solar radiation goes in the fluid flow path, double-skin facade heat transfer theory reacting to the airflow of the cavity takes into account the direction of airflow. Airflow is taken into consideration in the one dimension of building height direction. Each one of the factors of cavity space-outer skin, space media (air, etc.), and inner skin-have constant physical and thermal properties and temperature. The sky is viewed as a black body, and the temperature of the ground surface is viewed as the air temperature. Figure 2 illustrates an overview of the basic theory of heat transfer in double-skin facades. 


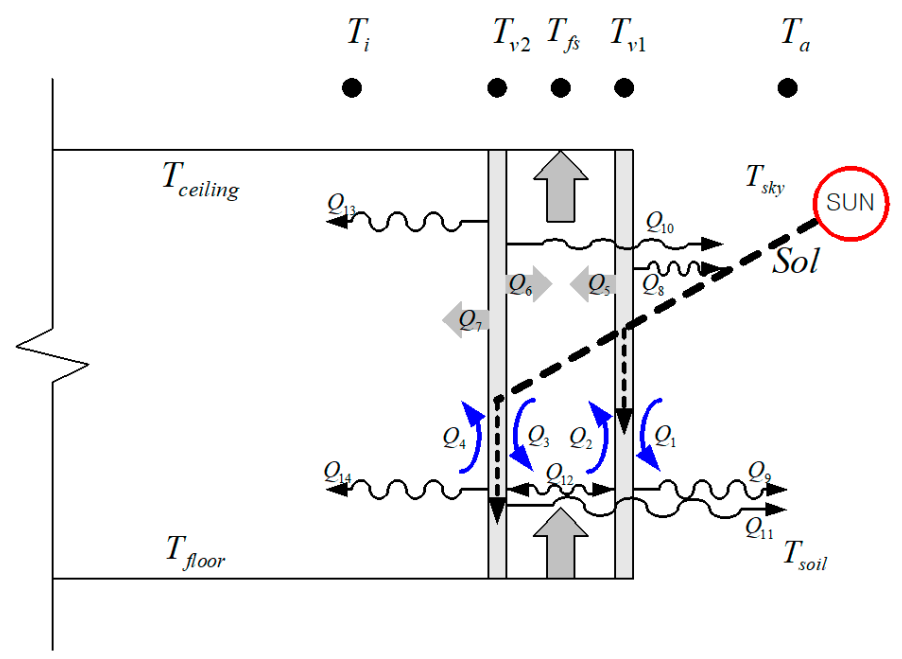

Figure 2. Overview of the basic theory of heat transfer in double-skin facades.

The heat transfer equation of the heat flow direction in each zone is presented as the Equations (1)-(3), respectively, each of which is the formula of the outer skin, cavity flow space, and inner skin. In this case, the transfer rates of conduction, convection, and radiation coming to the inside from the inner skin are integrated into one coefficient. If the cavity is closed, $\alpha=1$; if it has the state of airflow, $\alpha=0$.

$$
\begin{gathered}
K_{v 1} \frac{\partial T_{v 1}}{\partial t}=Q_{1}+(1-\alpha) Q_{2}+\alpha Q_{5}+Q_{5}+Q_{8}+Q_{9}+Q_{12}+\alpha_{v 1} \text { Sol } \\
K_{f s} \frac{\partial T_{f s}}{\partial t}+V_{f s} \frac{\partial T_{5 s}}{\partial Y}=-(1-\alpha) Q_{2}-(1-\alpha) Q_{3}-\alpha Q_{5}-\alpha Q_{6} \\
K_{v 2} \frac{\partial T_{v 2}}{\partial t}=(1-\alpha) Q_{3}+Q_{4}+\alpha Q_{6}+Q_{7}+Q_{10}+Q_{11}+Q_{12}+Q_{13}+Q_{14}+\tau_{v 1} \cdot \alpha_{v 2} S o l
\end{gathered}
$$

\subsection{Airflow Network Model}

An EnergyPlus building energy analysis simulation that implemented the airflow network was applied in order to analyze the improvement effects. The airflow network model of EnergyPlus is based on AIRNET developed by Walton in 1989. In integration with the EnergyPlus Air Heat Balance Manager module in EnergyPlus, a complex calculation is made by air mass and energy equilibrium equations.

In the 'Pressure and airflow calculations' step, external wind pressure and the node pressure and airflow by forced ventilation are calculated. Based on pressure and airflow calculations, the enthalpy of space is calculated through the temperature and absolute humidity of each node, the enthalpy of each air infiltration rate is totaled, and thereby the sensible heat and latent heating load of space are defined. Up to now, only the 'single heating and cooling system' using the 'single air distribution system' is applicable, and the heat capacity of the air duct is ignored. In a case where two zones are connected with components (air inlet and outlet areas) that have the relationship of airflow and pressure, it can be presented according to the airflow network model shown in Figure 3.

In order to verify and prove the performance improvement plan for the double-skin facade installed in the target building on the basis of the simulation theory for airflow analysis, this research investigated the overheating problem of the upper side of the double-skin facade through field measurement and analyzed the effects of the improvement plan. 


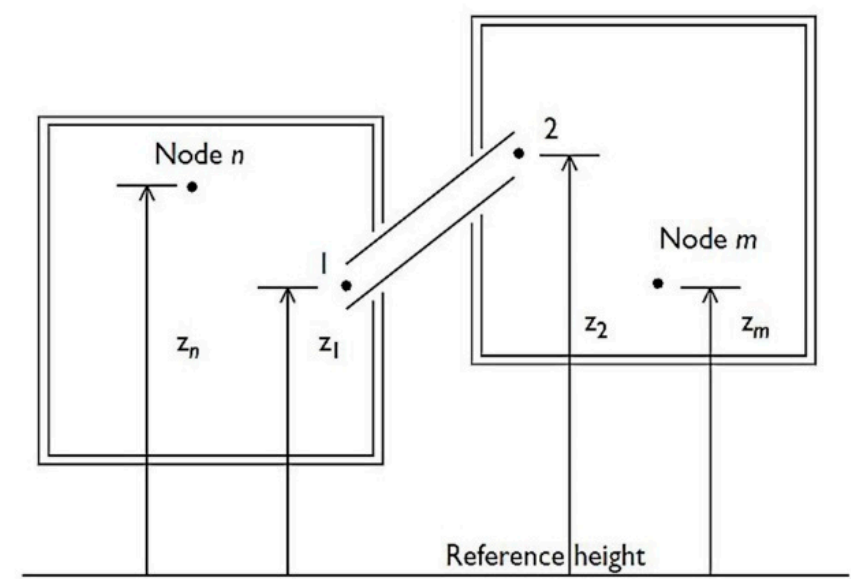

Figure 3. Concept map of the airflow network model.

\section{Verification of the Current State of Double-Skin Facade Operation by Field Measurement in Winter}

This study carried out a field measurement of a building with a double-skin facade and then analyzed the thermal phenomenon occurring in between the outer skin of the outside and the skin of the inside facing the building surface according to the effects of irradiance going into the double-skin facade cavity.

\subsection{The Current State of Double-Skin Facade Installation and Field Measurement Methodology}

This study chose as its target building the double-skin facade installed in the research and business facility of K Research Institute in Daejeon, South Korea. This building with a steel-frame structure has one floor below the ground and five floors above ground. The 1st floor is $4.5 \mathrm{~m}$ in height, and the 2nd to 5 th floors are $3.9 \mathrm{~m}$ in height. As shown in the overview, the building has its multistory double-skin facade on the south side, and the architectural information of the target building is presented in Table 1 .

Table 1. Details of measurement factors.

\begin{tabular}{ccc}
\hline Overview & Summer and Intermediate & Winter \\
\hline Dimensions & Exterior: $9 \mathrm{~mm}$ GN Green (Glazing) + Aluminum Curtain wall (Frame) \\
\hline Direction & Interior: $22 \mathrm{~mm}$ Clear $($ Glazing $)+$ Aluminum Fix \& PJ (Frame) \\
\hline Window composition & $30 \mathrm{~mm}$ granite burner finishing \\
\hline Inner wall finish & $44.6 \mathrm{~m}^{2}$ \\
\hline Lower air inlet area & $37.1 \mathrm{~m}{ }^{2}$ \\
\hline
\end{tabular}


The actual state of double-skin facade operation was analyzed. The inlet and outlet areas of the upper and lower sides of the double-skin facade are opened in summer. In this case, internal air with increased temperature by irradiance is emitted outside through natural ventilation. In winter, the outlet of the upper side of the double-skin facade is closed, and internal air with increased temperature is made to flow through the OA (outdoor air) inlet of the air conditioning system. At this time, the double-skin facade is used as the preheating path of outdoor air. In this way, it is possible to reduce outdoor air load and prevent heat loss. Therefore, if the double-skin facade is operated as shown in its design, it is possible to save energy.

In order to analyze the environmental factors of the double-skin facade influenced by the external environment, measurement factors and measurement points were chosen. Irradiance, regional surface temperature, and internal air temperature, which influence the inside of the double-skin facade, were measured. In order to quantitatively analyze the effects of the natural ventilation that occurs in the double-skin facade, the wind velocity of each one of the air inlet and outlet in the upper and lower sides of the double-skin facade was measured. Table 2 presents measurement factors and the applied measuring device.

Table 2. Details of measurement factors.

\begin{tabular}{|c|c|c|c|}
\hline Class & \multicolumn{2}{|c|}{ Measurement Factor } & Measuring Device \\
\hline \multirow{4}{*}{$\begin{array}{c}\text { External } \\
\text { Environment }\end{array}$} & \multicolumn{2}{|c|}{ Insolation on external vertical surface (IVS_E) } & $\begin{array}{l}\text { The Epply laboratory Inc. } \\
\text { Pyranometer } \\
\text { (Wavelength range: about } \\
300-2800 \mathrm{~nm} \text { ) }\end{array}$ \\
\hline & \multicolumn{2}{|c|}{ Outdoor dry bulb temperature (OT) } & $\begin{array}{c}\text { EI-1050 } \\
\text { (Temperature range: }-40-120^{\circ} \mathrm{C} \text { ) }\end{array}$ \\
\hline & \multicolumn{2}{|c|}{ Outdoor relative humidity } & EI-1050 (Range: 0 100\%) \\
\hline & \multicolumn{2}{|c|}{ External SAHTC meter } & Making referenced to NFRC 201 \\
\hline \multirow{8}{*}{$\begin{array}{c}\text { Internal } \\
\text { Environment }\end{array}$} & \multicolumn{2}{|c|}{ Air temperature at Inlet and outlet } & \multirow{5}{*}{$\begin{array}{c}\text { T-type thermocouple wire } \\
\left.\text { (Temperature range: }-200-350^{\circ} \mathrm{C}\right)\end{array}$} \\
\hline & \multirow{4}{*}{$\begin{array}{l}\text { Measurement Factors } \\
\text { for Each Floor }\end{array}$} & $\begin{array}{l}\text { Temperature of outer glazing } \\
\text { (OGT) }\end{array}$ & \\
\hline & & $\begin{array}{l}\text { Temperature of intermediate air } \\
\text { (IAT) }\end{array}$ & \\
\hline & & $\begin{array}{l}\text { Temperature of inner glazing } \\
\text { (IGT) }\end{array}$ & \\
\hline & & Temperature of inner wall (IWT) & \\
\hline & \multicolumn{2}{|c|}{ Air velocity at inlet and outlet } & $\begin{array}{l}\text { Kanomax multi-channel } \\
\text { anemomaster } \\
(0.1-50 \mathrm{~m} / \mathrm{s})\end{array}$ \\
\hline & \multicolumn{2}{|c|}{ Insolation on internal vertical surface (IVS_I) } & $\begin{array}{l}\text { The epply laboratory Inc. } \\
\text { Pyranometer } \\
\text { (Wavelength range: about } \\
300-2800 \mathrm{~nm} \text { ) }\end{array}$ \\
\hline & \multicolumn{2}{|c|}{ Internal SAHTC meter } & Making referenced to NFRC 201 \\
\hline
\end{tabular}

Figure 4 illustrates each measurement point of the measuring device, and the installation of the measuring sensor. In terms of irradiance, the irradiance on the external vertical surface of the double-skin facade was measured. As the measurement factors of the internal side, the surface temperature of the double-skin facade (outdoor side), air temperature, the surface temperature of the wall, and the temperature of the center of the glass window were measured on each floor. In the air inlet and outlet, air temperature and wind velocity were measured. 


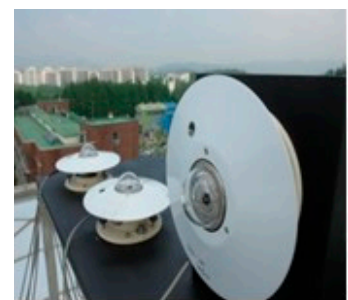

(a) Pyranometer (Outdoor)

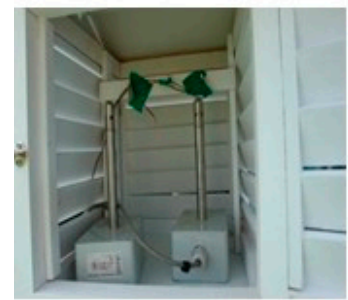

(d) Thermometer (Outdoor)

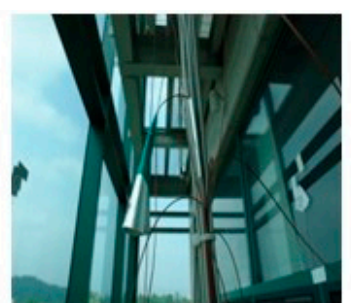

(b) Thermometer (In double skin façade)

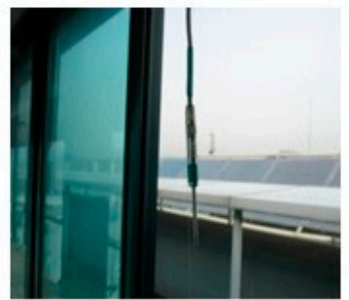

(e) Thermometer (Exhaust air)

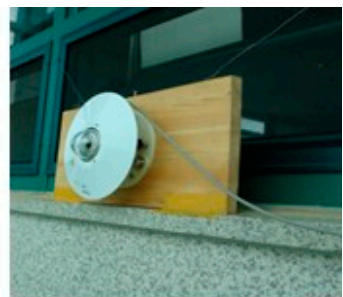

(c) Pyranometer (Building surface)

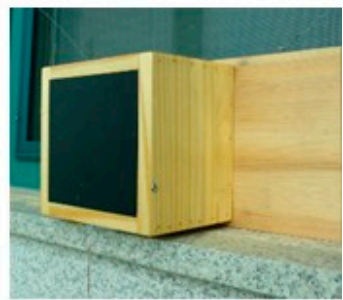

(f) SAHTC meter (Solar Air Heat Transfer Coefficient)

Figure 4. Photographs of Measuring Devices.

\subsection{Analysis of the Current State of Double-Skin Facade Operation in Winter}

Field measurement was carried out from June to December in order to analyze the actual operation state of the double-skin facade. As shown in Figure 5, daily average outdoor air temperature and accumulated irradiance of the multistory double-skin facade were analyzed during the measurement period. Outdoor air temperature gradually decreased with a seasonal change from summer (June) to winter (December), and the irradiance of the vertical side of the double-skin facade slowly increased as solar altitude lowered. To find the actual operation state of the double-skin facade in winter, the results of measurements which were made from October 26 to December 30 were analyzed. The main influence factors of the thermal environment were analyzed for the categories of irradiance level (high, middle low) on the basis of the irradiance of the vertical side, as shown in Table 3. Analysis days for each range were selected, and then the actual operation state of the double-skin facade was analyzed.

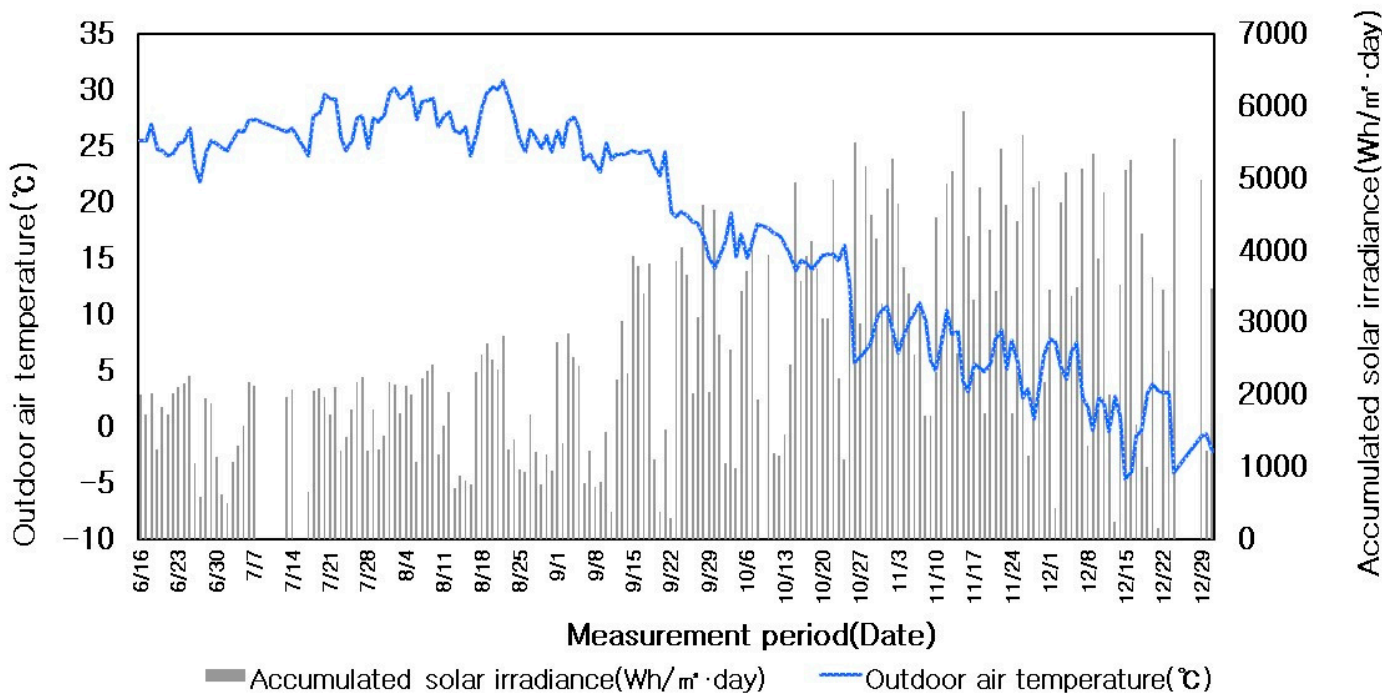

Figure 5. Solar irradiance and outdoor air temperature during the measurement period. 
Table 3. Analysis days in winter with temperature and solar irradiance.

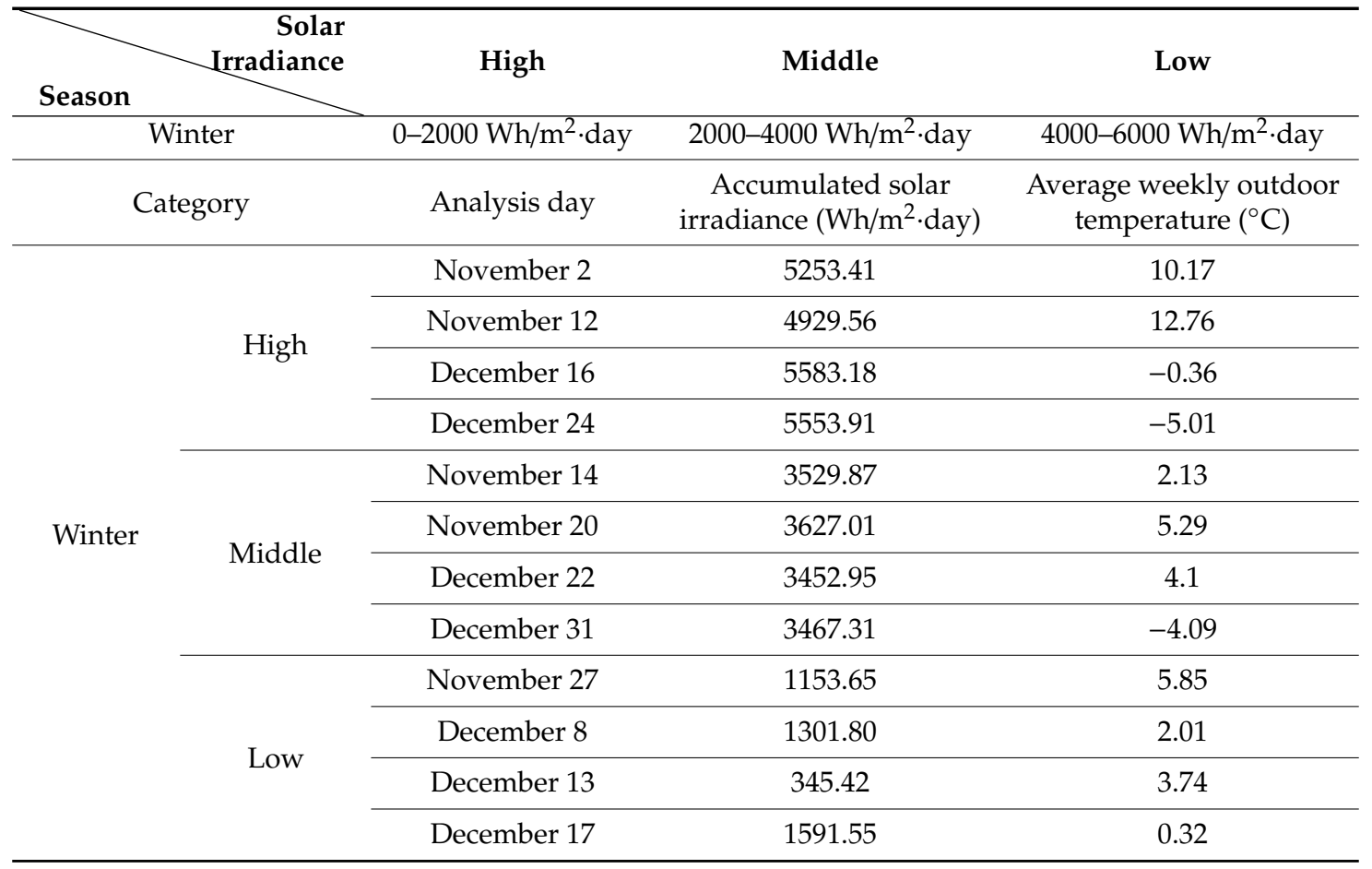

As shown in Figures 6 and 7, outdoor air temperature and irradiance were analyzed. When solar irradiance was at the high level, average outdoor air temperature and daily average accumulated irradiance in the daytime (8:00-17:00) were $5.79^{\circ} \mathrm{C}$ and $5249.49 \mathrm{Wh} / \mathrm{m}^{2}$.day. When irradiance was at the middle level, they were $1.9^{\circ} \mathrm{C}$ and $3519.29 \mathrm{Wh} / \mathrm{m}^{2}$.day. When irradiance was at the low level, they were $2.04{ }^{\circ} \mathrm{C}$ and $1102.23 \mathrm{Wh} / \mathrm{m}^{2}$. day. Outdoor air temperature in winter was lower than in summer and the intermediate period. However, the inflow irradiance of the multistory (vertical side) double-skin facade increased in winter as solar altitude was lowered.

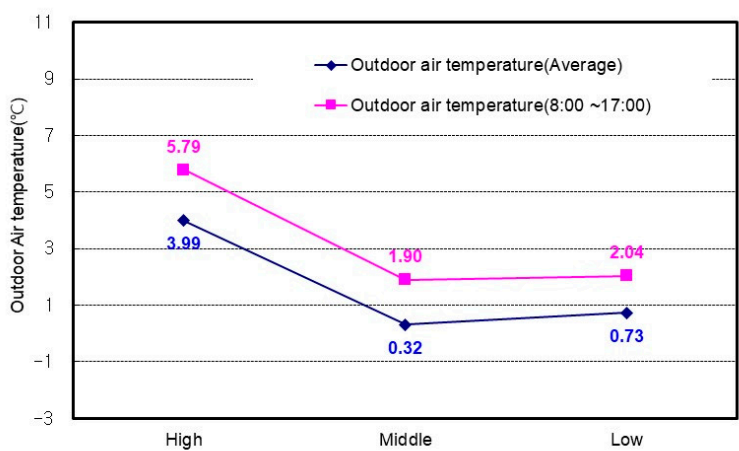

(a) Average outdoor air temperature

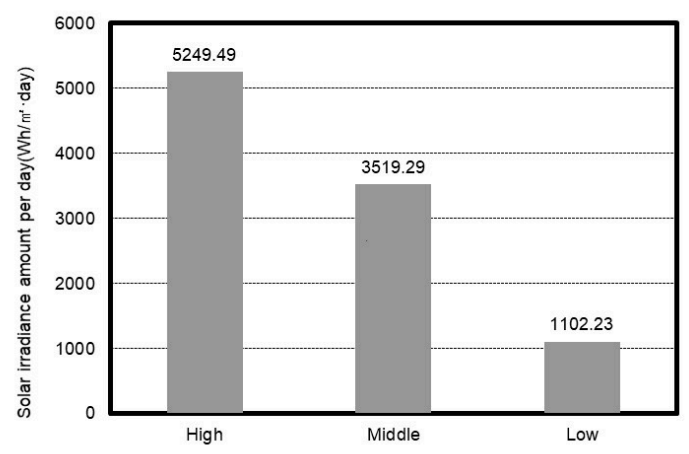

(b) Average solar irradiance in a day

Figure 6. Average outdoor air temperature and solar irradiance in winter. 

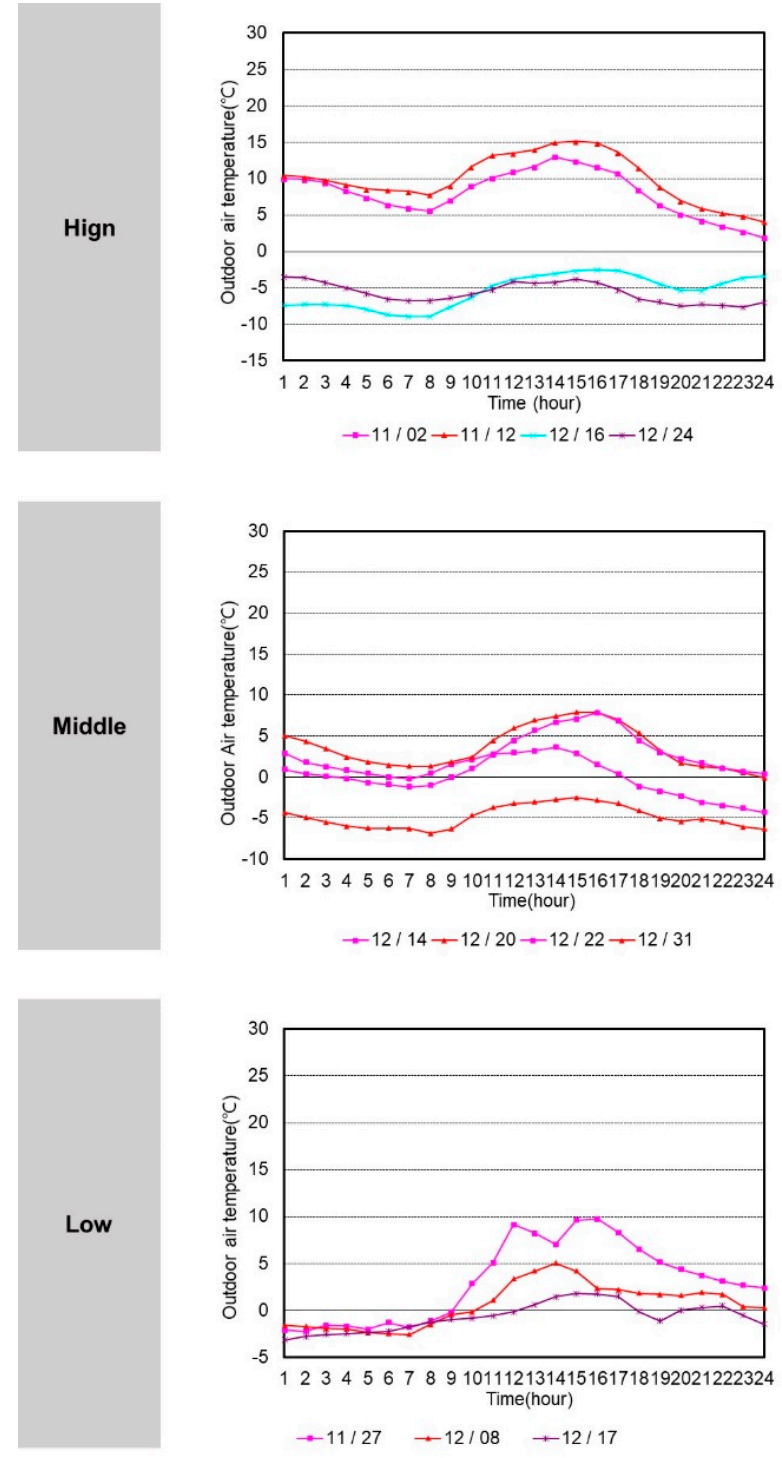

(a) Outdoor air temperature
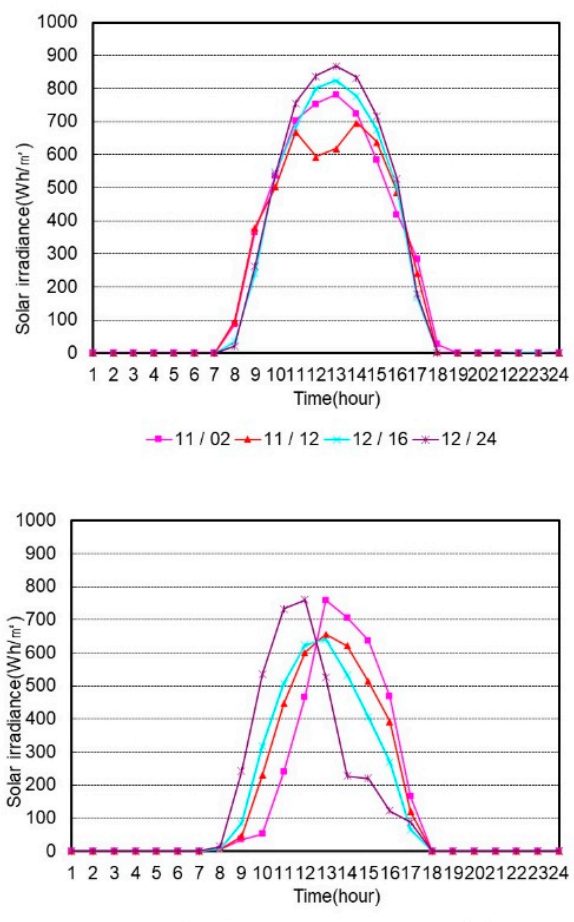

$-12 / 14 \rightarrow-12 / 20-12 / 22+12 / 31$

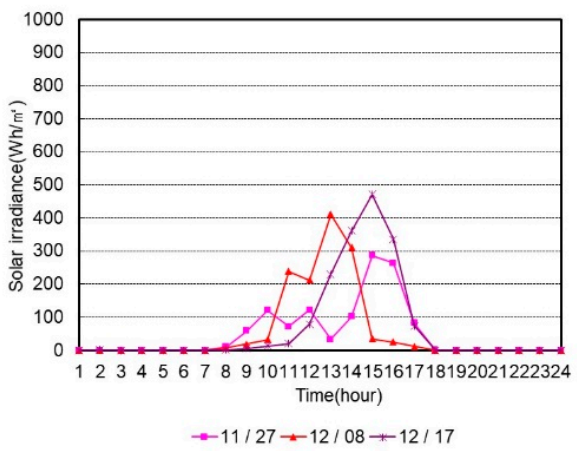

(b) Solar irradiance

Figure 7. Average outdoor air temperature and solar irradiance measurement results.

As presented in Figure 8, the internal air temperature for irradiance was analyzed. When irradiance was at the high level, the analysis date was December 16. Average outdoor air temperature in the daytime (8:00-17:00) was $-0.36{ }^{\circ} \mathrm{C}$ (max: $\left.3.13{ }^{\circ} \mathrm{C}, 13: 00\right)$, and the daily total accumulated irradiance of the multistory double-skin facade was $5583.18 \mathrm{Wh} / \mathrm{m}^{2}$.day (max: $823.87 \mathrm{Wh} / \mathrm{m}^{2}, 13: 00$ ). When solar irradiance was at the middle level, the analysis date was December 31. Average outdoor air temperature in the daytime (8:00-17:00) was $-4.09{ }^{\circ} \mathrm{C}$ ( $\left.\max :-2.62{ }^{\circ} \mathrm{C}, 15: 00\right)$, and the daily total accumulated irradiance of the multistory double-skin facade was $3491.63 \mathrm{Wh} / \mathrm{m}^{2}$.day (max: $760.55 \mathrm{Wh} / \mathrm{m}^{2}, 12: 00$; $\left.\min : 13.69 \mathrm{Wh} / \mathrm{m}^{2}, 8: 00\right)$. When solar irradiance was at the low level, the analysis date was December 13. Average outdoor air temperature in the daytime (8:00-17:00) was $3.74{ }^{\circ} \mathrm{C}$ (max: $5.2{ }^{\circ} \mathrm{C}, 16: 00$ ), and the daily total accumulated irradiance of the multistory double-skin facade was $345.42 \mathrm{Wh} / \mathrm{m}^{2}$.day (max: $74.75 \mathrm{Wh} / \mathrm{m}^{2}, 13: 00$ ). 

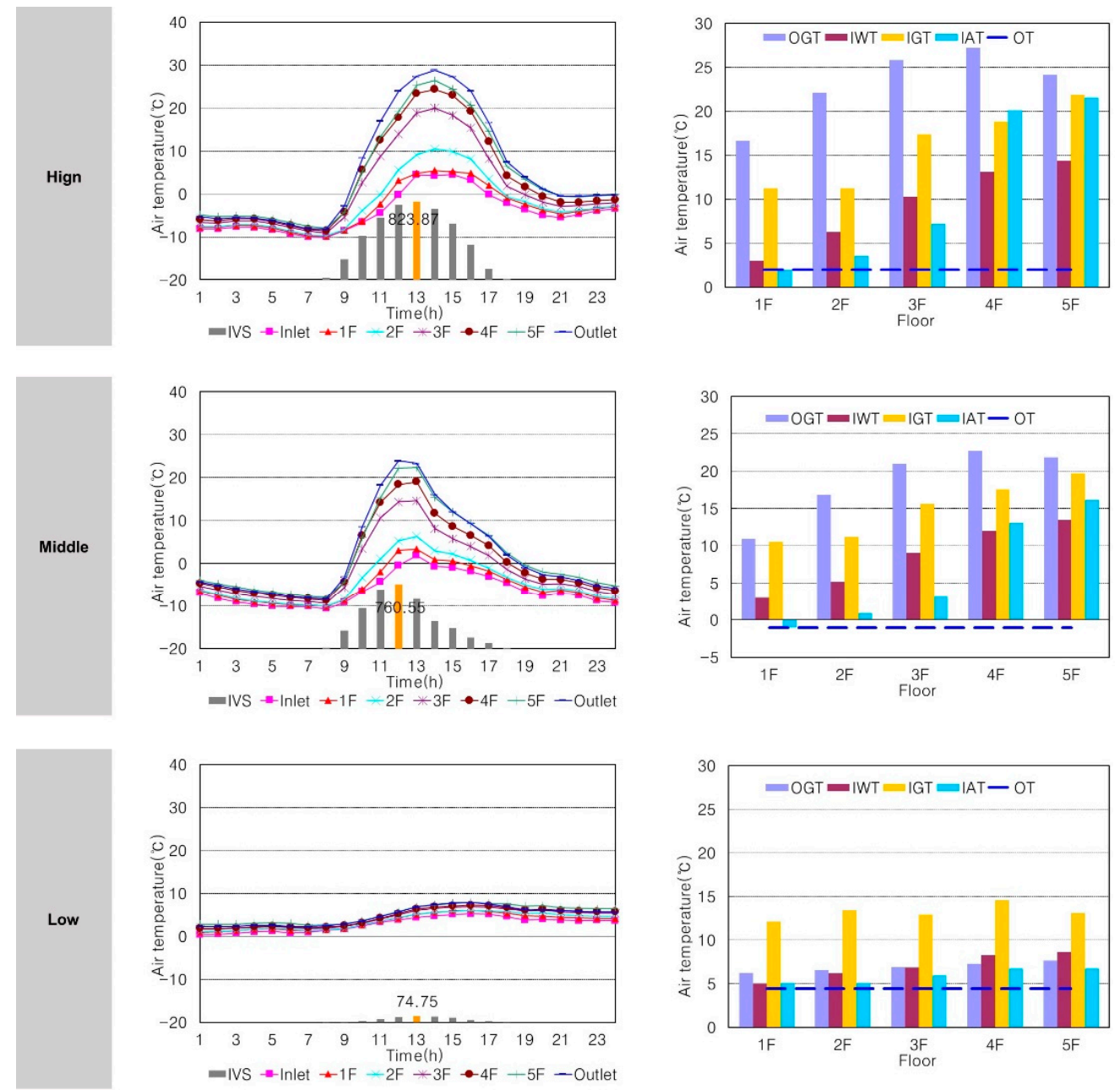

(a) Outdoor air temperature

(b) Air temperature distribution at each position

IVS : Solar irradiance at the vertical double façade surface, OGT : Outside glazing surface temperature IVS : Solar irradiance at the vertical double façade surface, OGT : Outside glazing surface temperature
IAT : Indoor glazing surface temperature, IGT : Indoor glazing surface temperature, IWT: Indoor wall surface temperature

Figure 8. Air temperature at double skin façade by solar irradiance in winter.

In winter, the outlet of the upper side is closed. The cavity's air with increased temperature is in connection with the OA (available air volume: $9600 \mathrm{CMH}$ (cubic meter per hour)) of the air conditioning system in the upper side. In other words, the double-skin facade is used not only as the preheating path of $\mathrm{OA}$ to reduce outdoor air load, but for the complex function of preventing heat loss from the inside to the outside resulting from air with increased temperature. In terms of the air temperature of the cavity, with a rise in solar irradiance, the temperature difference between the upper and lower air inlet and outlet areas increased, and the floor-to-floor stratification of air temperature was more distinct. On December 16 (when solar irradiance was at the high level), the temperature difference between the upper and lower air inlet and outlet areas was $24.15^{\circ} \mathrm{C}$ at 13:00, the maximum time of solar irradiance. On December 31 (when solar irradiance was at the middle level), the temperature difference between the upper and lower air inlet and outlet areas was $24.31{ }^{\circ} \mathrm{C}$ at $12: 00$, the maximum time of solar irradiance. On December 13 (when solar irradiance was at the low level), the temperature difference between the upper and lower air inlet and outlet areas was $24.15^{\circ} \mathrm{C}$ at $13: 00$, the maximum time of solar irradiance. Therefore, the overall temperature difference was large in winter, compared to other seasons. The stratification of cavity air temperature on each floor (height) was the most distinct when solar irradiance was at the high level in winter, just like in summer. The floor-to-floor temperature gradient was reduced as solar irradiance was lowered. The temperature gradient of the second and third floors was relatively larger in winter than in other seasons, and the temperature 
from the fourth floor to the exit was somewhat concentrated. It is judged that in winter, compared to other seasons, this temperature concentration was attributable to the reason that the low floors had more distinct stratification due to inflow and interference of outdoor air with low temperature, but the high floors had their air outlet closed and did not have enough preheated air through the double-skin facade in the way of utilizing OA of the air conditioning system in the duct in order to constantly keep the stratification structure. The temperature of each region of the cavity was analyzed on the basis of the average temperature measured at 11:00-16:00, a time slot that accounts for just over $60 \%$ of the daily accumulated irradiance of the multistory double-skin facade. Just as in other seasons, in winter, the surface temperature of the outer skin exposed to solar irradiance was the highest. However, on the analysis day when solar irradiance was at the low level, there was the lowest temperature distribution due to the interference of low outdoor air temperature for low irradiance heat absorption. With regard to the temperature difference of each region, the temperature of indoor window glass relatively vulnerable to heat resistance was high due to heat loss, since indoor heating air conditioning was applied. For this reason, the temperature difference of each region on the low floors was the largest. It was somewhat reduced on higher floors because of a rise in cavity air temperature. Just as with cavity air temperature, the temperature difference of each region was decreased as solar irradiance was lowered.

As shown in Figure 9, the wind velocity of the air inlet in the lower side in winter was analyzed. Unlike in other seasons, in winter, the air outlet in the upper side was closed and the preheated air through the double-skin facade was used as OA. For this reason, although the wind velocity of the air inlet in the lower side was somewhat different due to buoyancy according to irradiance, it remained at $0.8-1.2 \mathrm{~m} / \mathrm{s}$ on average in the daytime (8:00-17:00).

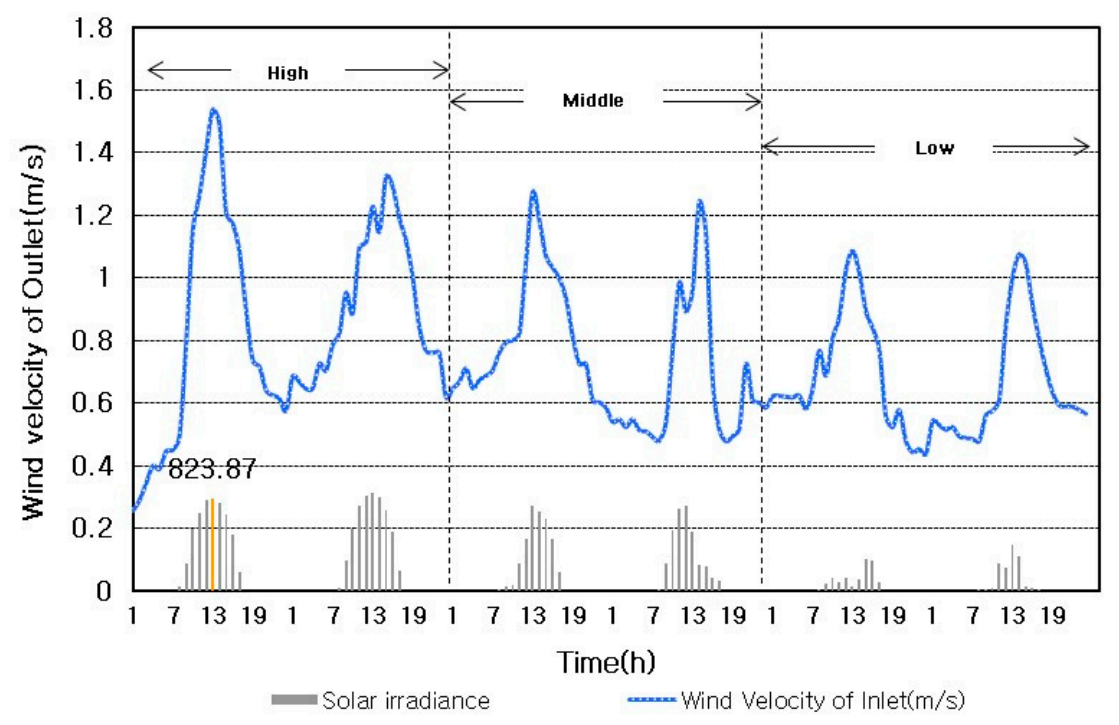

Figure 9. Wind velocity distribution of the Outlet in winter.

In terms of measuring the double-skin facade cavity in winter, the outlet of the upper side was closed in order to use the facade as the preheating path of air conditioning OA, and the cavity and air conditioning system interacted in terms of OA. According to the field measurement, the air with increased temperature through the double-skin facade had little OA utilization so that air stood still from the 4th floor to the exit area, and consequently temperature concentration occurred in the upper side. Nevertheless, in winter, the direction of intensive heat flow in the upper side was lost to the outside, not to the inside, due to the influence of low outdoor air temperature, and therefore, overheat transfer was not found in the upper side. In winter, if outer skin load and outdoor air load are reduced in the way of applying an appropriate air volume control strategy for OA utilization of the preheated air through the double-skin facade, it is possible to save a great deal of energy. 


\section{Analysis of the Effects of the Improvement Plan for Double-Skin Facade Operation}

In order to propose an indoor air conditioning energy reduction plan using preheated air through the double-skin facade, this study utilized a building energy analysis simulation to be implemented on the target building and then analyzed the effects of the improvement plan for the double-skin facade. An EnergyPlus simulation model was suggested that implemented the aforementioned airflow network and analyzed the ventilation performance and energy performance according to the application of alternative plans and thermal effect.

\subsection{Target Building Modeling and OA-Based System Design}

Through target building modeling (baseline), the building energy analysis simulation that implemented a double-skin facade was executed. In comparison with the results of the aforementioned field measurement, the validity of the simulation model was verified. Table 4 presents information on the building modeling. As alternative plans(ALT) for activating the internal airflow of the double-skin facade, double-skin facades with solar chimney systems were suggested, as illustrated in Table 5.

Table 4. Input information of the baseline simulation model.

\begin{tabular}{|c|c|c|c|c|c|}
\hline Part & Material & $\begin{array}{l}\text { Thickness } \\
\text { (m) }\end{array}$ & $\begin{array}{l}\text { U-Value } \\
\left(\mathrm{W} / \mathrm{m}^{2} \mathrm{~K}\right)\end{array}$ & SHGC & Baseline Model \\
\hline (1) External glass & $\begin{array}{l}9 \text { mm green } \\
\text { glass }\end{array}$ & 0.009 & 5.38 & 0.521 & \\
\hline (2) Internal glass & $\begin{array}{c}6 \mathrm{~mm} \text { clear } \\
\text { glass } \\
12 \mathrm{~mm} \text { air gap } \\
6 \mathrm{~mm} \text { clear } \\
\text { glass }\end{array}$ & 0.024 & 2.7 & 0.701 & \\
\hline (3) Outer wall & $\begin{array}{l}\text { Granite stone } \\
\text { Air layer } \\
\text { Metal sheet } \\
\text { Air layer } \\
\text { Insulation } \\
\text { Gypsum board }\end{array}$ & 0.32 & 0.395 & - & \\
\hline $\begin{array}{l}\text { (4) Wall of the upper side of } \\
\text { the double-skin facade }\end{array}$ & $\begin{array}{l}\text { Aluminum } \\
\text { sheet } \\
\text { insulation }\end{array}$ & 0.083 & 0.465 & - & \\
\hline (5) Roof & $\begin{array}{l}\text { Plain concrete } \\
\text { Mortar } \\
\text { Waterproof } \\
\text { sheet } \\
\text { Concrete slab } \\
\text { Insulation }\end{array}$ & 0.368 & 0.418 & - & \\
\hline \multicolumn{6}{|c|}{$\begin{array}{l}\text { Inner skin window-to-wall ratio: } 0.5 . \\
\text { Internal heat generation conditions: device load } 25 \mathrm{~W} / \mathrm{m}^{2} \text {, lighting load } 17 \mathrm{~W} / \mathrm{m}^{2} \text {, occupancy density } 8 \mathrm{~m}^{2} / \text { person. } \\
\bigcirc \text { Cooling and heating set temperature: cooling } 28^{\circ} \mathrm{C} \text {, heating } 20^{\circ} \mathrm{C}(08: 00-18: 00) . \\
\bigcirc \text { Simulation time step: } 1 \text { min. }\end{array}$} \\
\hline
\end{tabular}


Table 5. Solar chimney systems as alternative plans.

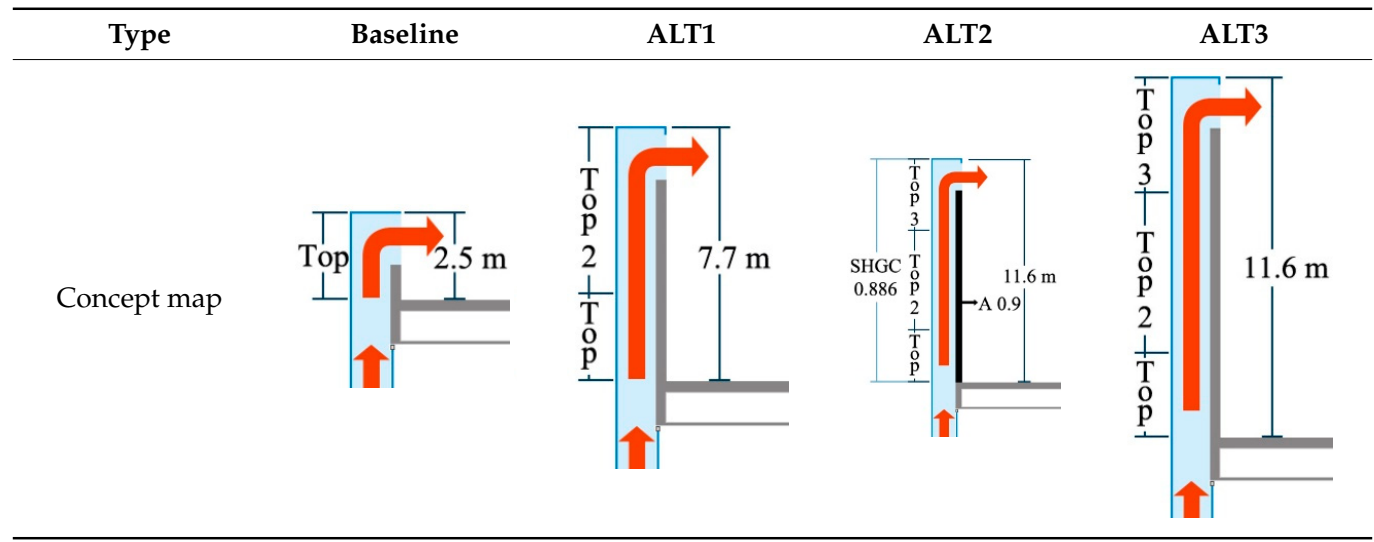

Each alternative plan replaced the outlet height (TOP) position of the baseline model. According to the installation height of the solar chimney (SC), the temperature of the inside of the double-skin facade, airflow, and indoor load were analyzed. The outlet height (TOP) of the upper side of the double-skin facade in the baseline model showed no great difference from the height of a reference floor. Therefore, this study established the following plans-the 2nd floor height of the SC (ALT1: $7.5 \mathrm{~m}$ ), the 3rd floor height of the SC (ALT2: $11.6 \mathrm{~m}$ ), and the thermal effect implementation for increasing the solar transmittance of the outer skin and the insolation absorptance of the inner wall (ALT3) in order to activate buoyancy-induced airflow by increasing the temperature of the SC path-and analyzed their effects.

In winter, the double-skin facade secures the outer skin insulation performance of the installation side to reduce outer skin load, as shown in Figure 10, and is used as the preheating path of OA flowing in the internal AHU (Air Handling Unit) in order to reduce the outdoor air load of air conditioning. In this study, the SC proposed to improve the heat performance of the double-skin facade increases the solar heat use capacity and OA preheating amount of the double-skin facade so that it can save more heating energy in winter. Therefore, in winter evaluation, the indoor heating load and the OA-based heat through the double-skin facade according to OA-based air volume were analyzed in each proposed alternative plan using an SC.

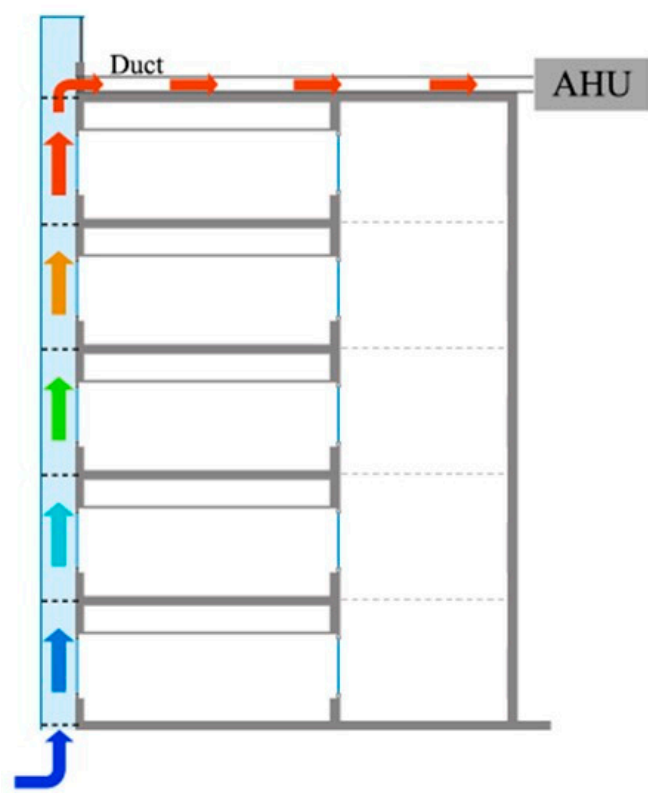

Figure 10. Concept of the simulation model for outdoor air (OA)-based air conditioning in winter. 
The total area of the air conditioning zone of the double-skin facade was $19,440 \mathrm{~m}^{3}$. As shown in the table, the indoor heating load and OA-based heat of the installation side of the double-skin facade were calculated according to the OA-based air volume (air changes $0.2 / \mathrm{h}-2 / \mathrm{h}$ ) through the double-skin facade in each alternative plan with an SC. The indoor heating load and OA-based heat were added together (OA-based heat-indoor heating load), and then an appropriate air volume for the designed air change in each alternative plan was selected. On the basis of the baseline model (OA-based air volume: $9600 \mathrm{CMH}$ ) actually operated by the double-skin facade, the relative energy performance improvement value of the selected appropriate air volume in each alternative plan with an SC was analyzed. According to the daily accumulated irradiance of the multistory double-skin facade as the dominant influential factor on the thermal behavior of the double-skin facade, they were divided

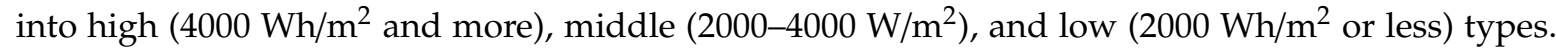
The simulation period was 95 days of heating operation from 1 November to 15 March. Heating load was calculated only in the south air conditioning zone $(1 \mathrm{~F}-5 \mathrm{~F})$ directly influenced by the double-skin facade. In terms of climate data, outdoor air temperature and humidity, measured data of solar irradiance, and wind direction and velocity data of relevant regions, which are offered by Korea Meteorological Administration, were used.

\subsection{Analysis Results of the Operation Improvement Plan}

Figure 11 shows the measurement results on the $x$-axis and the simulation results on the $y$-axis in the same time zones, reacting to the same external environments on the selected analysis days, according to the solar irradiance levels in terms of cavity air temperature in order to verify the airflow network simulation baseline model in summer. Based on the linear equation with a y-intercept of ' 0 ', if the coefficient of $x$ value and $R 2$ value are close to ' 1 ', it is proved that the measurement values are highly consistent with simulation values. According to the comparison, the coefficient to $x$ value was 0.98 , and $\mathrm{R} 2$ was 0.96 . As a result, there was a considerably high level of consistency.

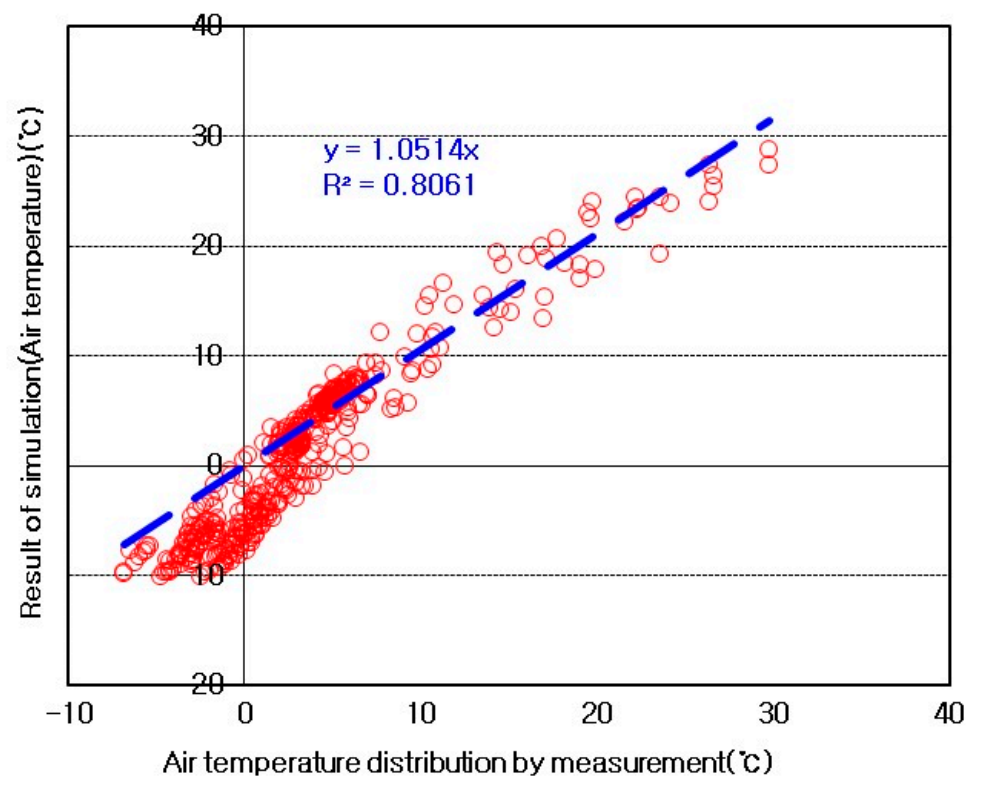

Figure 11. Comparison of air temperature between measurement and simulation results.

Figure 12 shows the double-skin facade-based heat and indoor heating load for the period (November to March) according to the OA-based air volume. In terms of double-skin facade-based heat, when solar irradiance was at the high and middle levels, each alternative plan showed that with a rise in OA-based air volume, the double-skin facade-based heat gradually increased and remained almost unchanged in the range of about $26,000 \mathrm{CMH}$ and above. When solar irradiance was at the low 
level, each alternative plan showed that with a rise in OA-based air volume, the double-skin facade heat gradually increased, and remained almost unchanged and then decreased to a value in the range of about 15,000 CMH and above. In each alternative plan, with the application of an SC and a rise in its height, the double-skin facade-based heat also increased. The ALT3, which implemented thermal effect, showed the highest heat value. On balance, with an increase in the amount of irradiance of the double-skin facade, the OA-based air volume also went up. Additionally, with the application of an SC to the upper side of the double-skin facade, solar heat was used more, and therefore the OA utilization through the double-skin facade was larger.
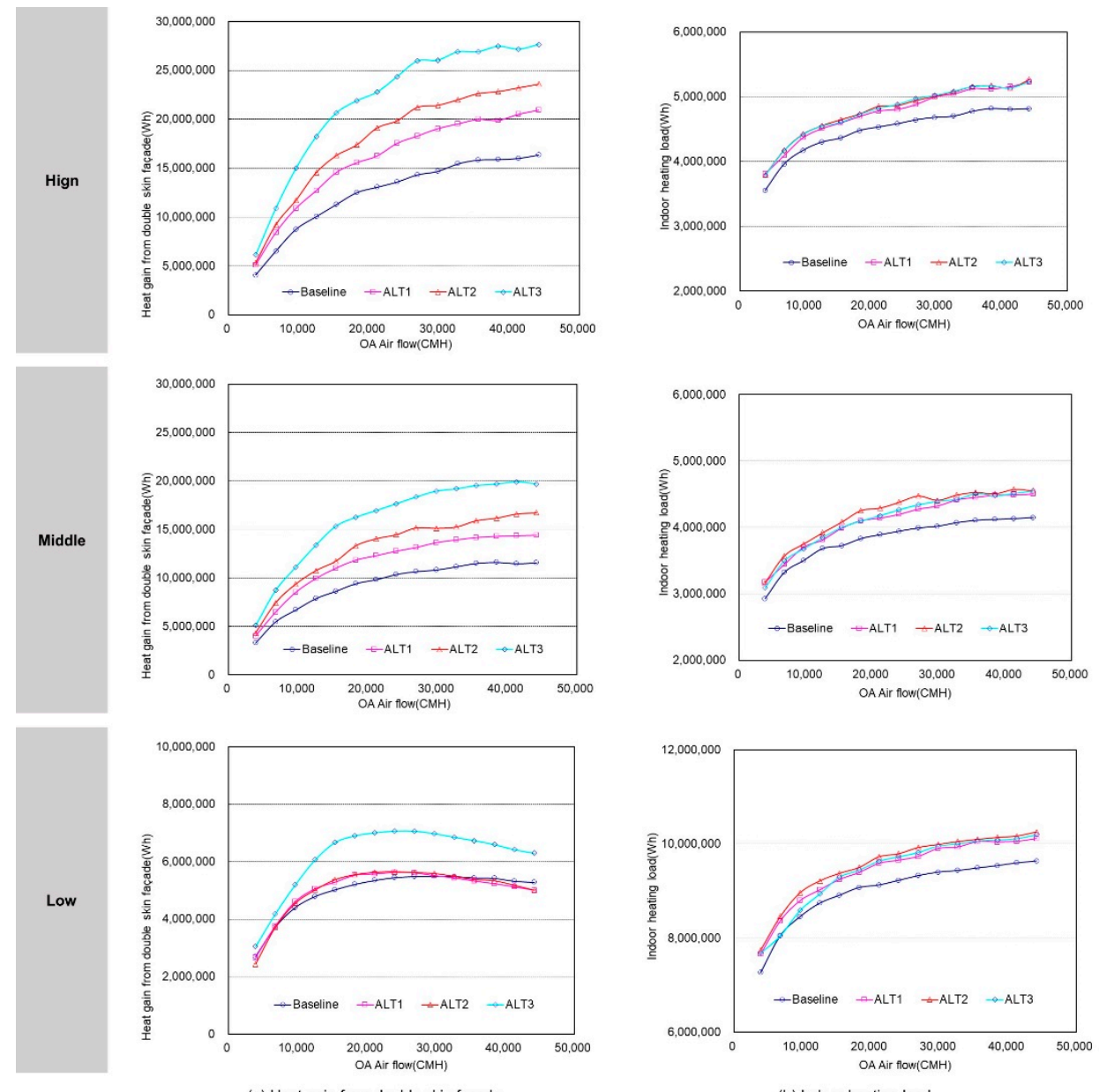

(a) Heat gain from double skin façade

(b) Indoor heating load

Figure 12. Heat gain and heating load from simulation results.

In terms of annual heating load according to the double-skin facade-based air volume, with a rise in OA-based air volume, the temperature distribution by cavity height and the surface heat resistance of the inner wall were lowered and therefore indoor heating load gradually increased, but it was lower than of the the double-skin facade-based heat. Compared to the baseline model, each alternative plan showed that with the application of an SC and a rise in its height, the buoyancy of the air of the cavity caused heat concentration on the SC path and thereby the $1 \mathrm{~F}$ to $5 \mathrm{~F}$ cavity air temperature was relatively lowered and indoor load somewhat increased. Nevertheless, ALT1, ALT2, and ALT3 had a similar distribution of annual heating load without any great difference.

Figure 13 illustrates the analysis results of the double-skin facade-based heat production in each alternative plan according to OA-based heat and solar irradiance. The double-skin facade-based heat production proposed in this study is the total of the double-skin facade-based heat and indoor heat loss load by each OA-based air volume. It refers to the net heat production at the time when the 
double-skin facade is used as the preheating path of OA. When the daily accumulated irradiance of the multistory double-skin facade was $2000 \mathrm{Wh} / \mathrm{m}^{2}$ and more, the double-skin facade-based heat was larger than the indoor heat loss load. When it was less than $2000 \mathrm{Wh} / \mathrm{m}^{2}$, indoor heat loss load was relatively larger, and therefore, general loss occurred. In the analysis of each alternative plan, the heat produced by the double-skin facade increased in the order of Baseline $<$ ALT1 $<$ ALT2 $<$ ALT3 as an SC was applied and its height went up. The ALT3, which implemented thermal effect on the SC path, produced the highest heat.

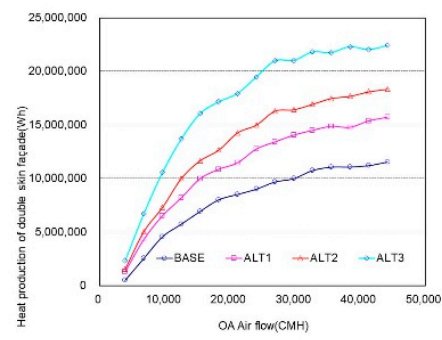

(a) High solar irradiance

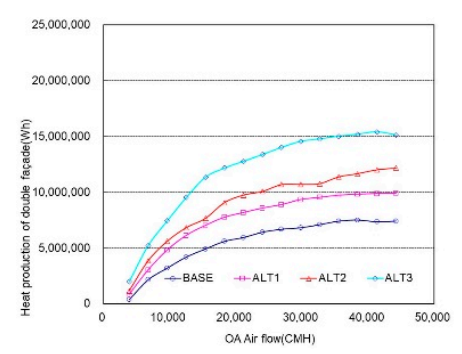

(b) Middle solar irradiance

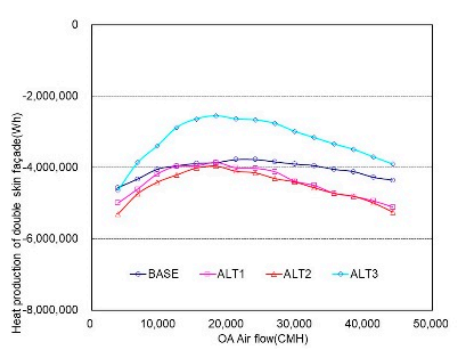

(c) Low solar irradiance

Figure 13. Heat gain of the double skin facade by ALT and solar irradiance.

Figure 14 presents the air temperature of the cavity in each alternative plan on the analysis days of solar irradiance selected at the time of measurement. With a rise in solar irradiance, the temperature difference between the upper and lower sides in the double-skin facade was larger. With an increase in the installation height of the SC, there was no great difference in the air temperature of the cavity close to indoor $(1 \mathrm{~F}-5 \mathrm{~F})$ in each plan. However, the air temperature in the SC path gradually increased with a rise in the SC height. The highest temperature increase occurred in ALT3.

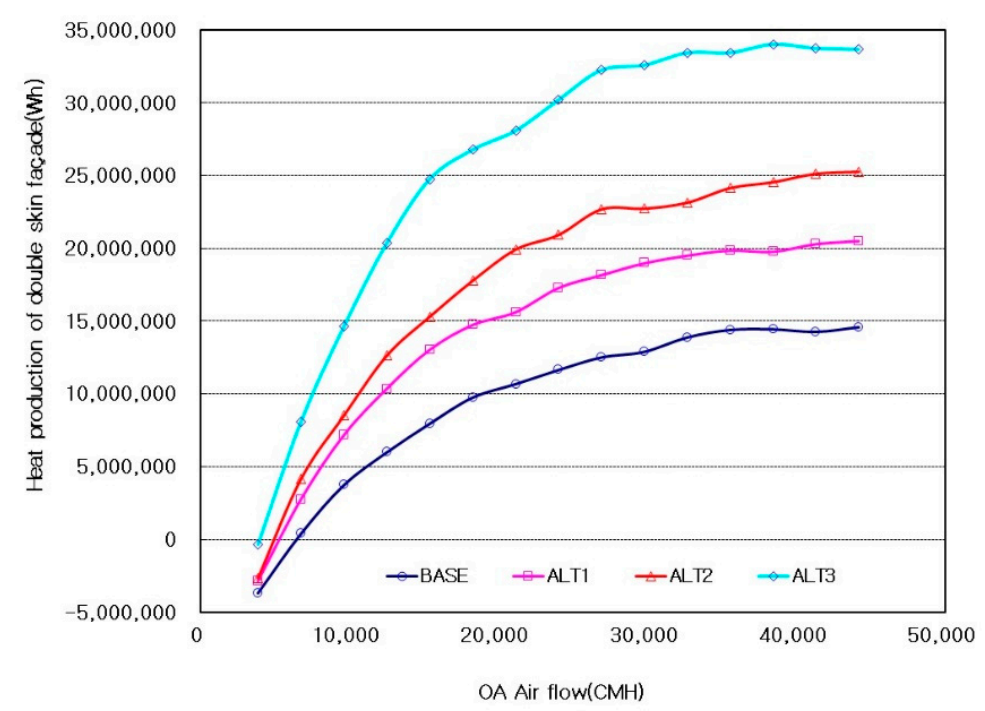

Figure 14. Heat production of the double skin facade by the OA airflow of the ALT.

This study chose a range of constant increase of double-skin facade-based heat with a rise in OA-based air volume as an appropriate OA-based air volume range. Therefore, when solar irradiance was at the high and middle levels, $2600 \mathrm{CMH}$ was chosen as the maximum OA-based air volume; when at the low level, $1500 \mathrm{CMH}$ was chosen as the maximum OA-based air volume. When the solar irradiance of all the air conditioning zones of the building was at the high and middle levels, the number of maximum air changes was 1.3 times/h; when the solar irradiance was at the low level, it was 0.7 times/h. These numbers met the ventilation requirement of 0.7 times/h and above prescribed in 'Rules of Building Facilities Standards, Etc. (2006)' of the Ministry of Land, Transport and Maritime Affairs. 
Air changes for introducing fresh outdoor air can be different depending on the operation intention of building and on irradiance. Therefore, when solar irradiance was at the high and middle levels, three operation plans (number of air changes: 0.7, 1, and 1.3 times/h) were established, and then the temperature, pressure, and heat production of the double-skin facade cavity were analyzed according to the number of air changes.

The cavity air temperature on the analysis days for solar irradiance in winter was analyzed according to the number of air changes. Figure 15 shows the average cavity air temperatures in the daytime (11:00-16:00) on analysis days when solar irradiance was at the high and middle levels according to the number of air changes. The lower the solar irradiance was, the smaller the cavity air temperature difference and overall temperature distribution in the upper and lower sides of the double-skin facade were. The cavity air temperatures in each alternative plan were analyzed. As a result, in all alternative plans, a similar temperature rise inclination remained from $1 \mathrm{~F}$ to TOP. With the application of an SC and a rise in its height, the temperature rise inclination found in the lower side of the SC (1F-TOP) remained constant, and the temperature in the SC zone gradually increased. However, in the ALT 3 that implemented thermal effect, the temperature rise inclination in the SC zone was relatively larger, and thereby the temperature was the highest. With an increase in the number of air changes, the temperature rise inclination in all zones of the double-skin facade became smaller and the temperature went down overall.
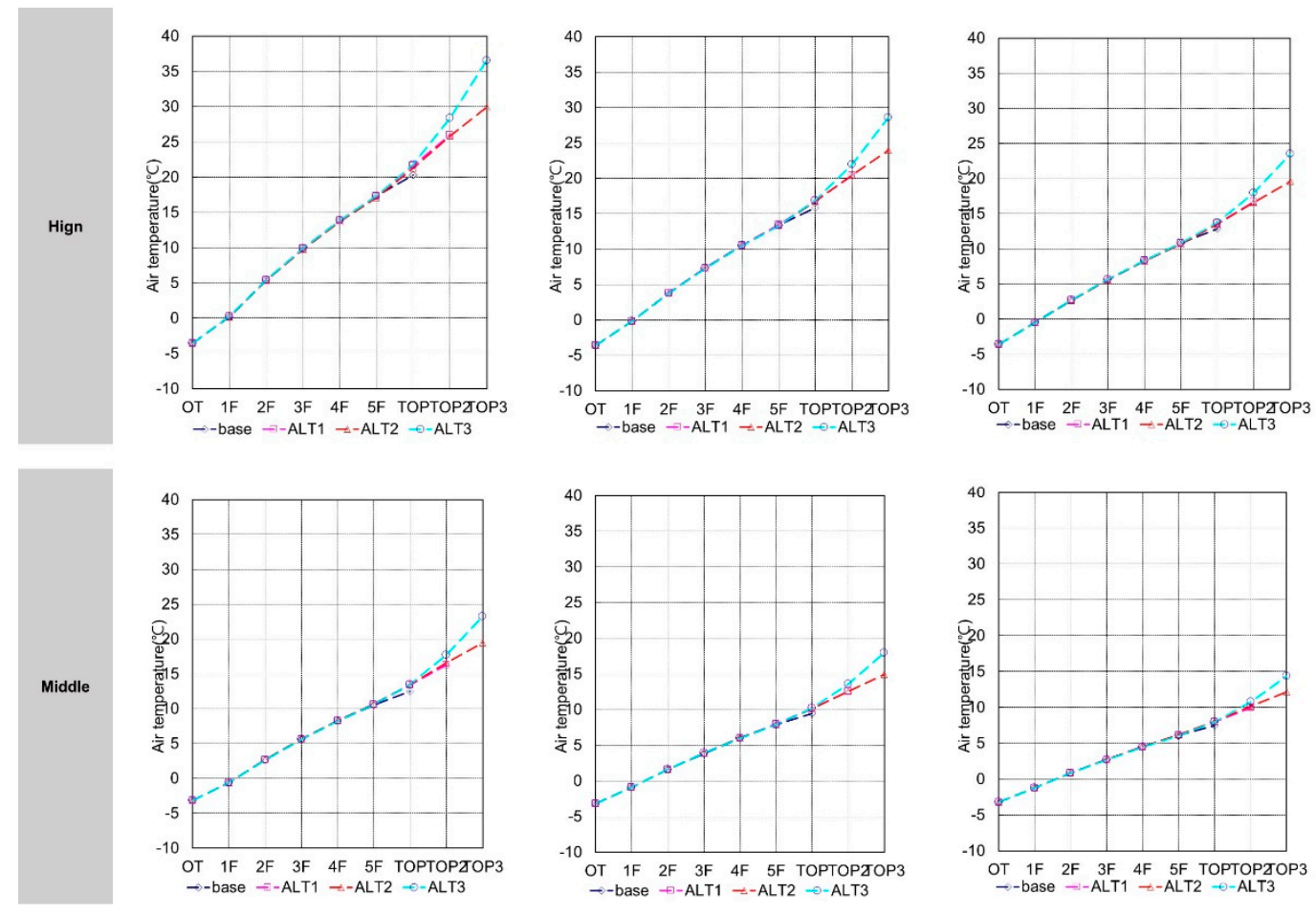

(a) $\mathrm{ACH} 0.7$

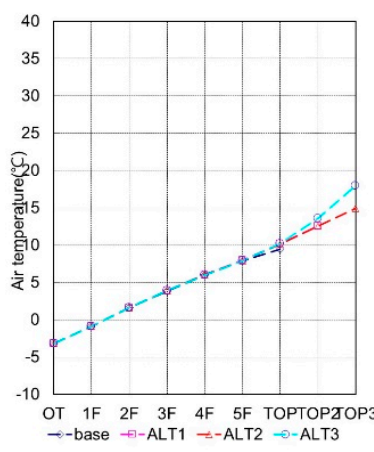

(b) $\mathrm{ACH} 1.0$

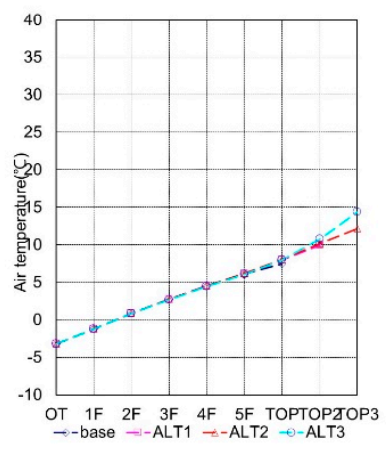

(c) $\mathrm{ACH} 1.3$

Figure 15. Air temperature distribution by $\mathrm{ACH}$ (air change per hour) with high and middle levels of solar irradiance.

Figure 16 illustrates the average cavity pressure in the daytime (11:00-16:00) on the analysis days when solar irradiance was at the high level, according to the number of air changes. With a decrease in solar irradiance, the pressure difference and overall pressure in the upper and lower sides of the double-skin facade were smaller. Each alternative plan had the following cavity pressure:

In all the alternative plans, a similar pressure rise inclination remained from $1 \mathrm{~F}$ to TOP. With the application of an SC and a rise in its height, the pressure rise inclination found in the lower side of the SC (1F-TOP) remained constant, and the pressure in the SC zone gradually increased. However, 
in the ALT 3 that implemented thermal effect, the pressure rise inclination in the SC zone was relatively larger, and thereby the pressure was the highest. With an increase in the number of air changes, the temperature difference and air density difference in the vertical direction of the double-skin facade became smaller and the pressure went down overall.
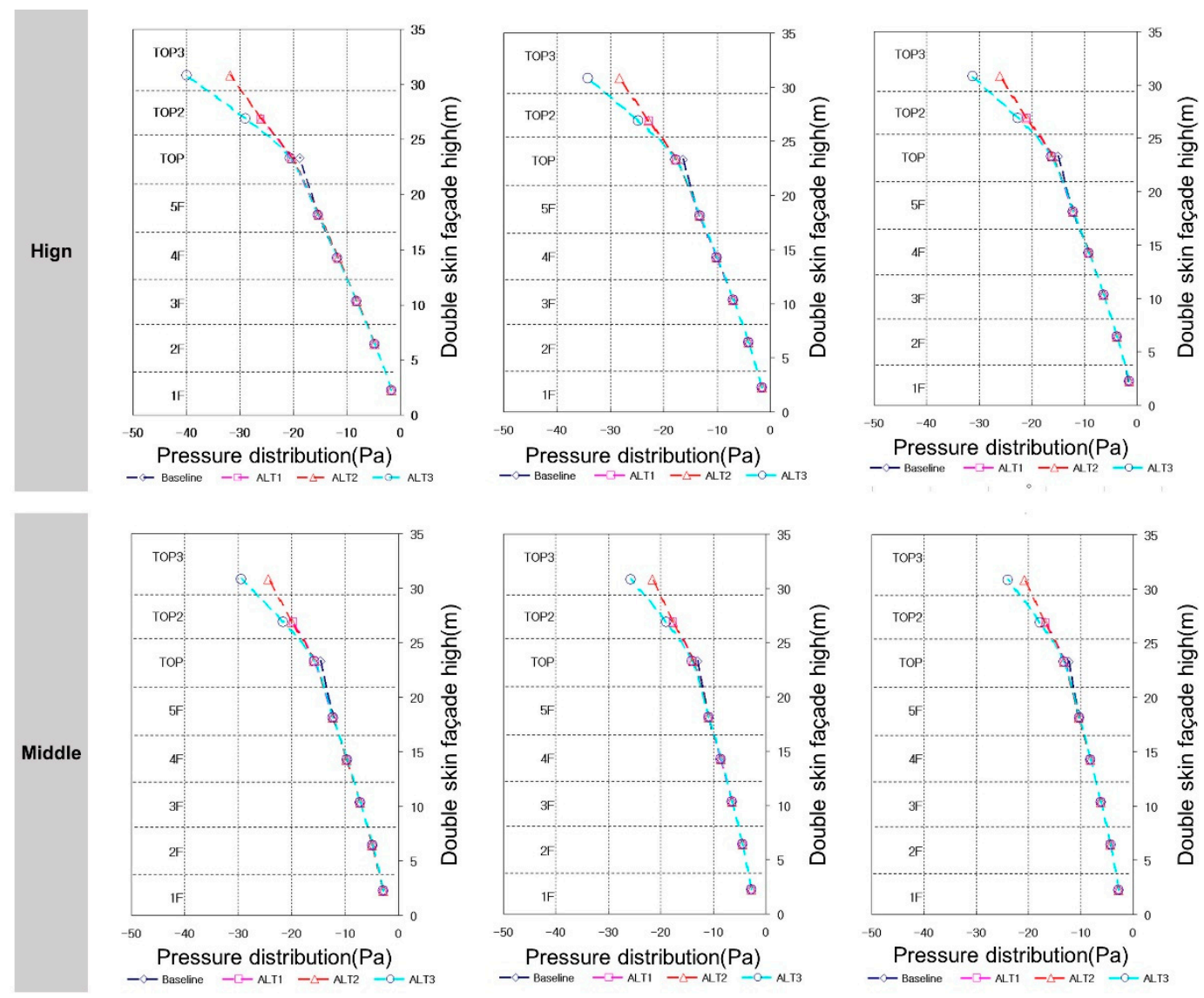

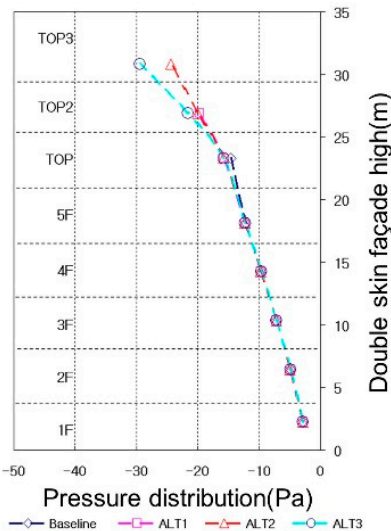

(a) $\mathrm{ACH} 0.7$

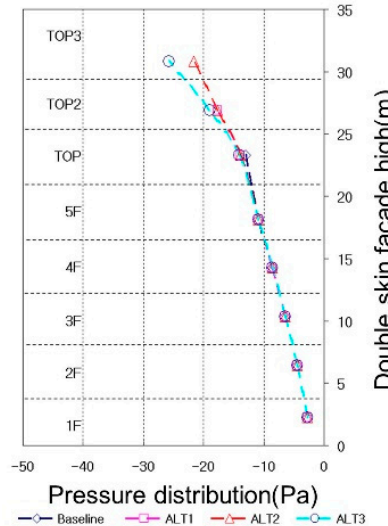

(b) $\mathrm{ACH} 1.0$

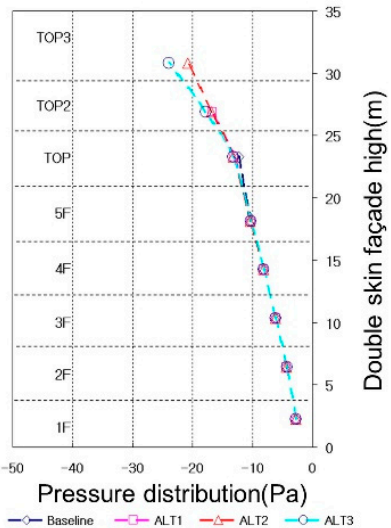

(c) $\mathrm{ACH} 1.3$

Figure 16. Pressure distribution by $\mathrm{ACH}$ with high and middle levels of solar irradiance.

Figure 17 presents the average cavity air temperature and pressure in the daytime (11:00-16:00) when solar irradiance was at the low level. In terms of cavity air temperature, in all the alternative plans, a similar temperature rise inclination remained. However, with the application of an SC and a rise in its height, the temperature in the SC zone remained almost same as the temperature in the TOP with no temperature rise. In the ALT 3 that implemented thermal effect, the air temperature somewhat increased in the SC zone, but its temperature rise was smaller than that in the 1F-TOP zone. The overall temperature distribution was lower than that at the time when solar irradiance was at the high and middle levels. In terms of cavity air temperature, the application of an SC and a rise in its height and thermal effect were not influential. In all the alternative plans, a small and similar pressure rise inclination remained in each vertical zone. As the temperature difference and air density difference in the vertical direction of the double-skin facade became smaller, the pressure was lower than that at the time when solar irradiance was at the high and middle levels. 

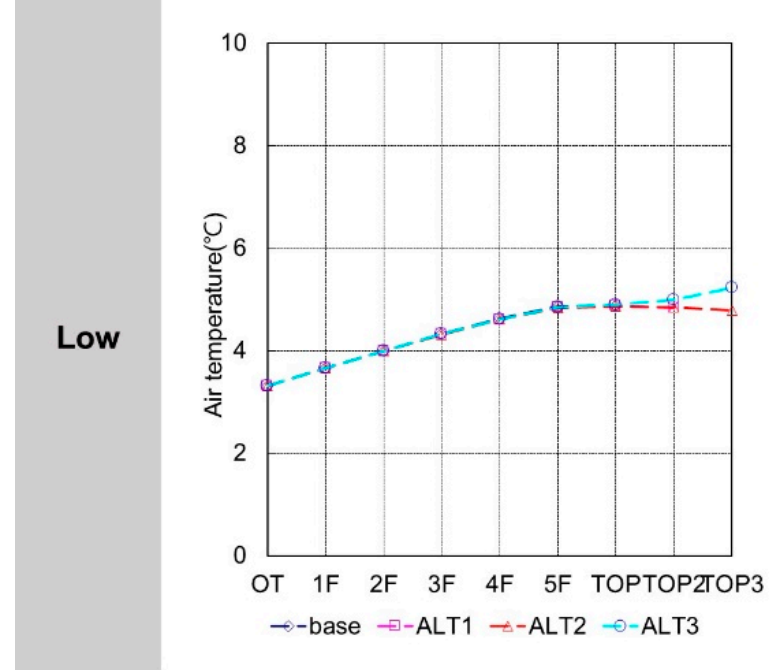

(a) Air temperature $(\mathrm{AHC} 0.7)$

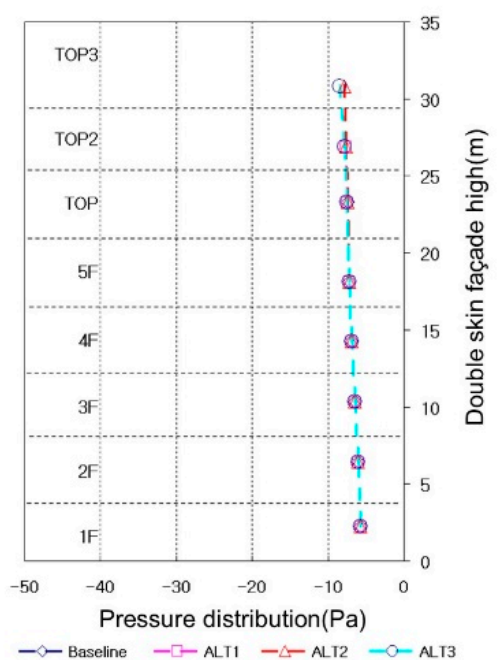

(b) Pressure distribution( $\mathrm{ACH} 0.7$ )

Figure 17. Air temperature and pressure distribution with low solar irradiance.

Figure 18 illustrates the temperature difference and pressure difference on the top and bottom in each alternative plan on the basis of the average cavity air temperature and pressure in the daytime (11:00-16:00) on analysis days when solar irradiance was at the high, middle, and low levels. A temperature difference is the reference to judge the available heat of the double-skin facade, presenting the difference between the top temperature and outdoor air temperature in each alternative plan. A pressure difference means the difference between the top pressure and the bottom (1F) pressure in each alternative plan. With a rise in the solar irradiance of the double-skin facade, the temperature and pressure differences between the top and bottom in each alternative plan increased. In particular, the ALT 3 that implemented thermal effect showed the largest temperature and pressure differences by available air volumes, showing the highest possibility of heat production. When solar irradiance was at the low level, all alternative plans showed similar temperature and pressure differences, so that energy production with the use of solar heat was not different in each alternative plan.

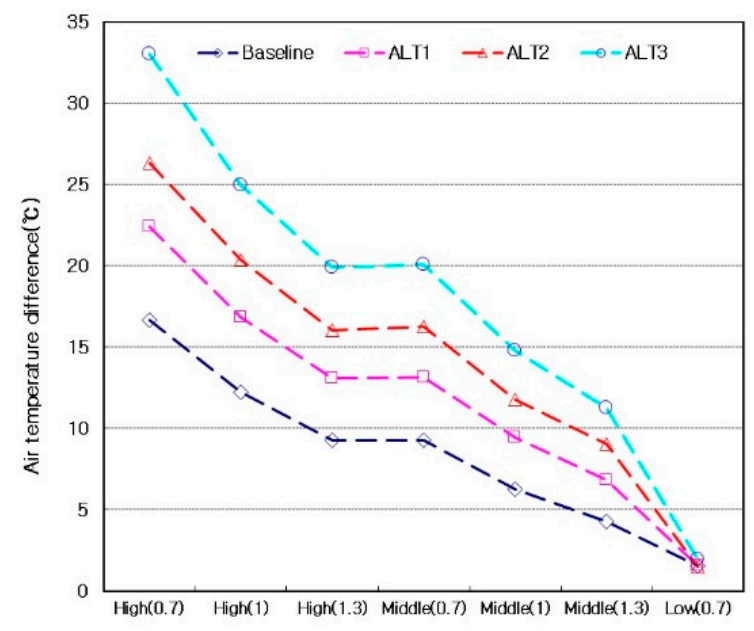

(a) Air temperature( $\mathrm{AHC}$ 0.7)

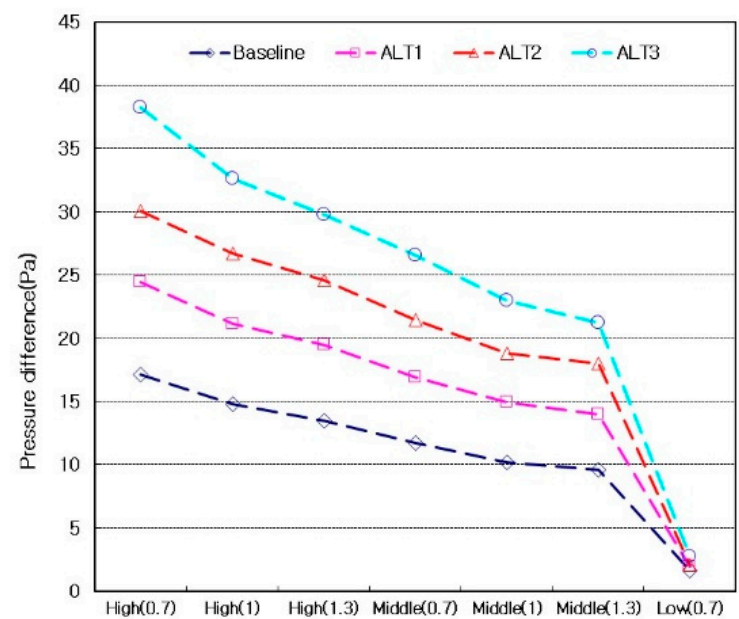

(b) Pressure distribution( $\mathrm{ACH}$ 0.7)

Figure 18. Air temperature and pressure difference by $\mathrm{ACH}$.

The annual indoor heating load according to the application of an SC and OA-based air volume was analyzed. Table 6 shows the heating air conditioning time in each alternative plan. BASE $(\mathrm{O})$ is the 
heating air conditioning time when the original OA-based air volume was applied to the double-skin facade used in this study. The lower the solar irradiance was, the higher the OA-based air volume was and the greater the heating air conditioning time was. So, the baseline model had the smallest heating air conditioning time overall. Based on the ALT1 with the greatest heating air conditioning time, the average outdoor air temperature of heating air conditioning time in each one of the high, middle, and low levels of solar irradiance was calculated. As a result, the outdoor air temperature was highest in the order of low level $\left(3.44^{\circ} \mathrm{C}\right)>$ middle level $\left(0.65^{\circ} \mathrm{C}\right)>$ high level $\left(-3.54^{\circ} \mathrm{C}\right)$ of solar irradiance.

Table 6. Air conditioning time (h) by ALT and AHC.

\begin{tabular}{|c|c|c|c|c|c|c|}
\hline Category & BASE(O) ${ }^{1)}$ & AHC & Baseline & ALT1 & ALT2 & ALT3 \\
\hline \multirow{3}{*}{ High } & \multirow{3}{*}{148} & 0.7 & 153 & 156 & 157 & 157 \\
\hline & & 1.0 & 156 & 158 & 163 & 158 \\
\hline & & 1.3 & 159 & 162 & 166 & 164 \\
\hline \multirow{3}{*}{ Middle } & \multirow{3}{*}{176} & 0.7 & 182 & 187 & 185 & 187 \\
\hline & & 1.0 & 185 & 191 & 196 & 190 \\
\hline & & 1.3 & 190 & 193 & 198 & 195 \\
\hline \multirow[t]{2}{*}{ Low } & 398 & 0.7 & 398 & 420 & 403 & 403 \\
\hline & & 0.7 & 733 & 763 & 745 & 747 \\
\hline \multirow[t]{2}{*}{ Total } & 722 & 1.0 & 739 & 769 & 762 & 751 \\
\hline & & 1.3 & 747 & 775 & 767 & 762 \\
\hline
\end{tabular}

1) ACH 0.4 (OA airflow $9600 \mathrm{CMH})$.

Figure 19 shows the annual indoor heating load in each alternative plan according to solar irradiance. Compared to the BASE (O) model, all alternative plans had relatively higher heating loads. Figure 20 presents the total heating load (including indoor heating load) according to solar irradiance. As shown in the figure, with the application of an SC and a rise in its height, and also an increase in OA-based air volume, the load was high overall. However, the ALT3 that applied thermal effect to the SC had a somewhat lower load than ALT2. Therefore, ALT2 had the highest annual indoor heating load.

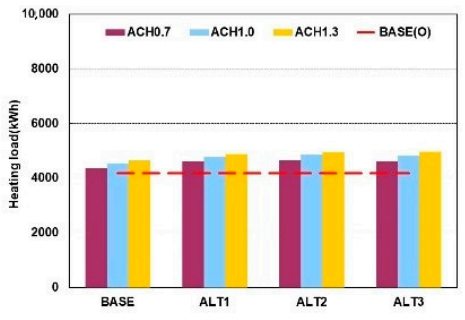

(a) High level solar irradiance

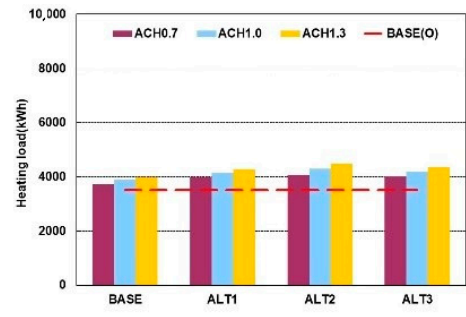

(b) Middle level solar irradiance

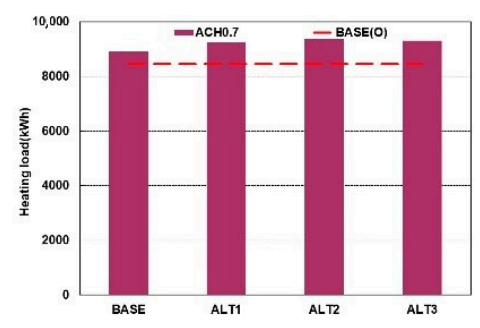

(c) Low level solar irradiance

Figure 19. Annual heating load of ALT by solar irradiance level. 


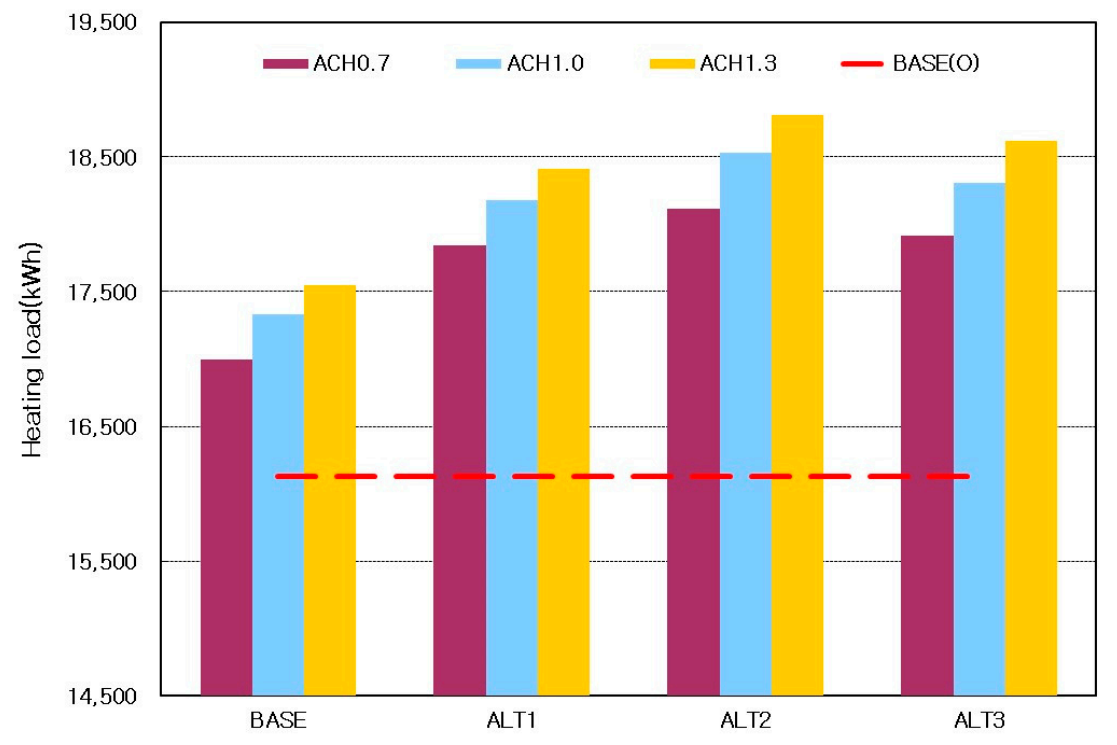

Figure 20. Heating load distribution by ACH of ALTs.

Figure 21 illustrates the annual double-skin facade-based heat in each alternative plan according to solar irradiance. All alternative plans had higher heat than the BASE $(\mathrm{O})$ model. Figure 22 presents the total available heat (including the heat using the solar heat of the double-skin facade) according to solar irradiance. As shown in the figure, with the application of an SC and a rise in its height, and an increase in OA-based air volume, the heat was high overall. The ALT3 that applied thermal effect to the SC had the highest annual double-skin facade-based heat.

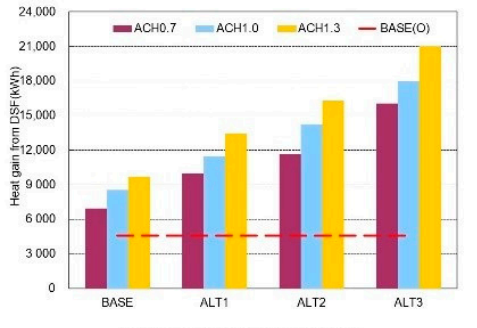

(a) High level solar irradiance

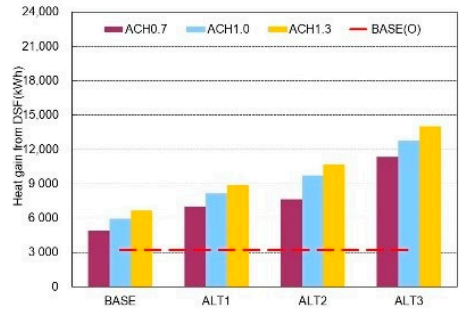

(b) Middle level solar irradiance

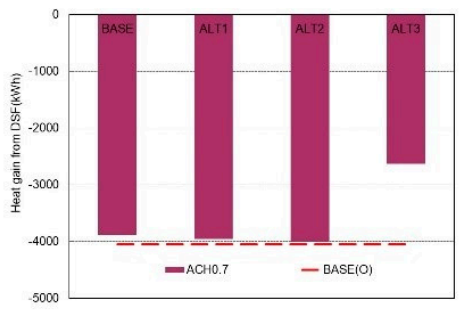

(c) Low level solar irradiance

Figure 21. Annual heat production of ALT by solar irradiance.

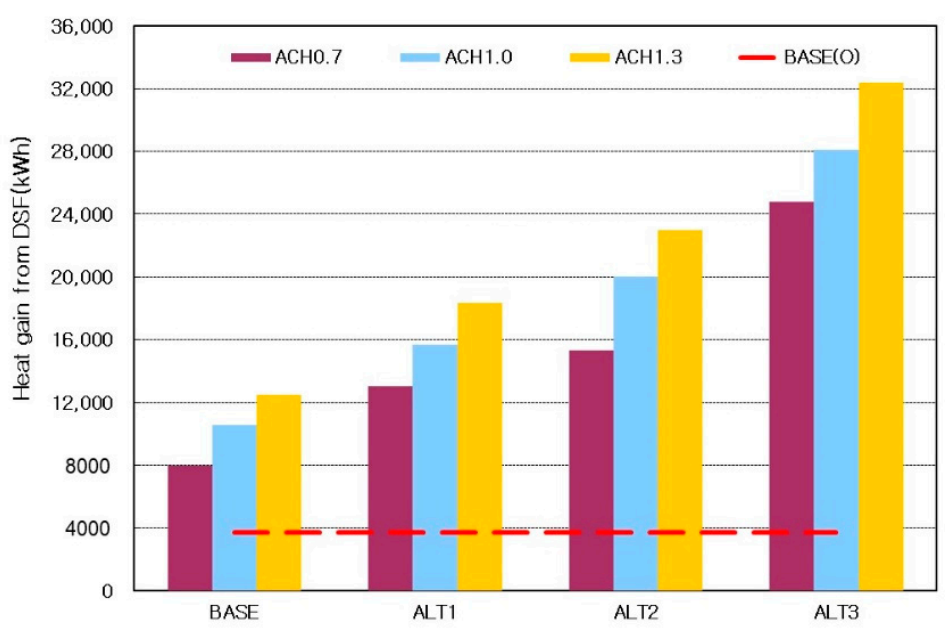

Figure 22. Heat production distribution by ACH of ALT. 
Figure 23 shows the heating energy use rate of each alternative plan for the BASE $(\mathrm{O})$ model in terms of the original OA-based air volume of the double-skin facade. With the application of an SC and a rise in its height, the available capacity of the solar irradiance of the double-skin facade increased, and thereby the use rate of heating energy increased. With a rise in the OA-based air volume in each alternative plan, the use rate also increased. The ALT3 that applied thermal effect to the SC had the highest heating energy use rate. When ACH was 1.3, it was possible to use heating energy about 7.6 times higher than the BASE $(\mathrm{O})$ model. Figure 24 presents the annual heating energy production capacity of the double-skin facade in each alternative plan according to OA-based air volume. The heating energy production capacity of the double-skin facade presents the heating loss load ratio in the installation side of the double-skin facade for the net solar heat-based energy of the double-skin facade of the building, which uses the cavity as the preheating path of air conditioning OA.

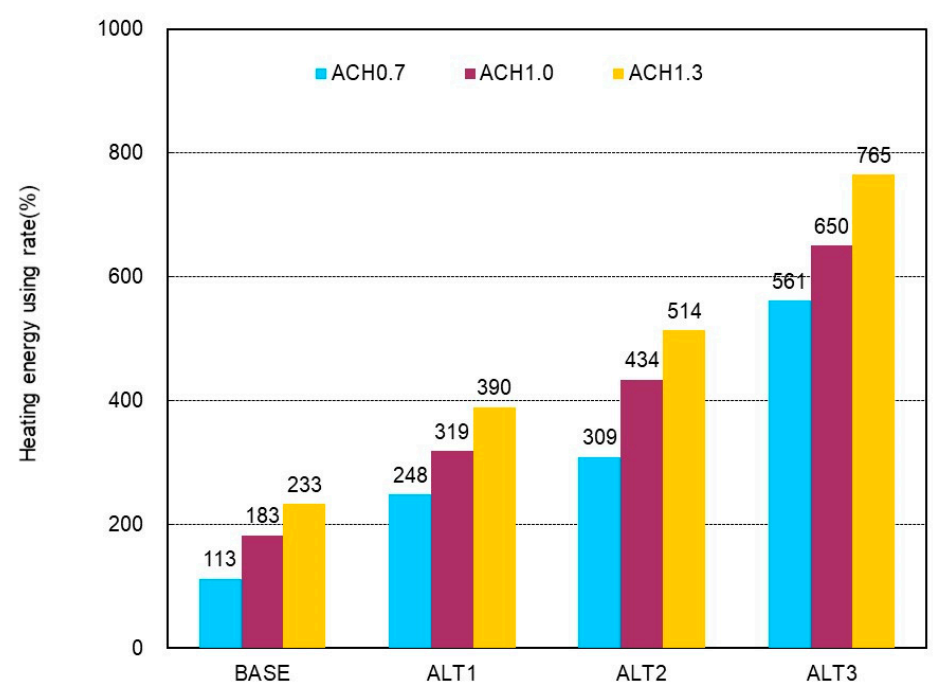

Figure 23. Heat energy using rate by $\mathrm{ACH}$.

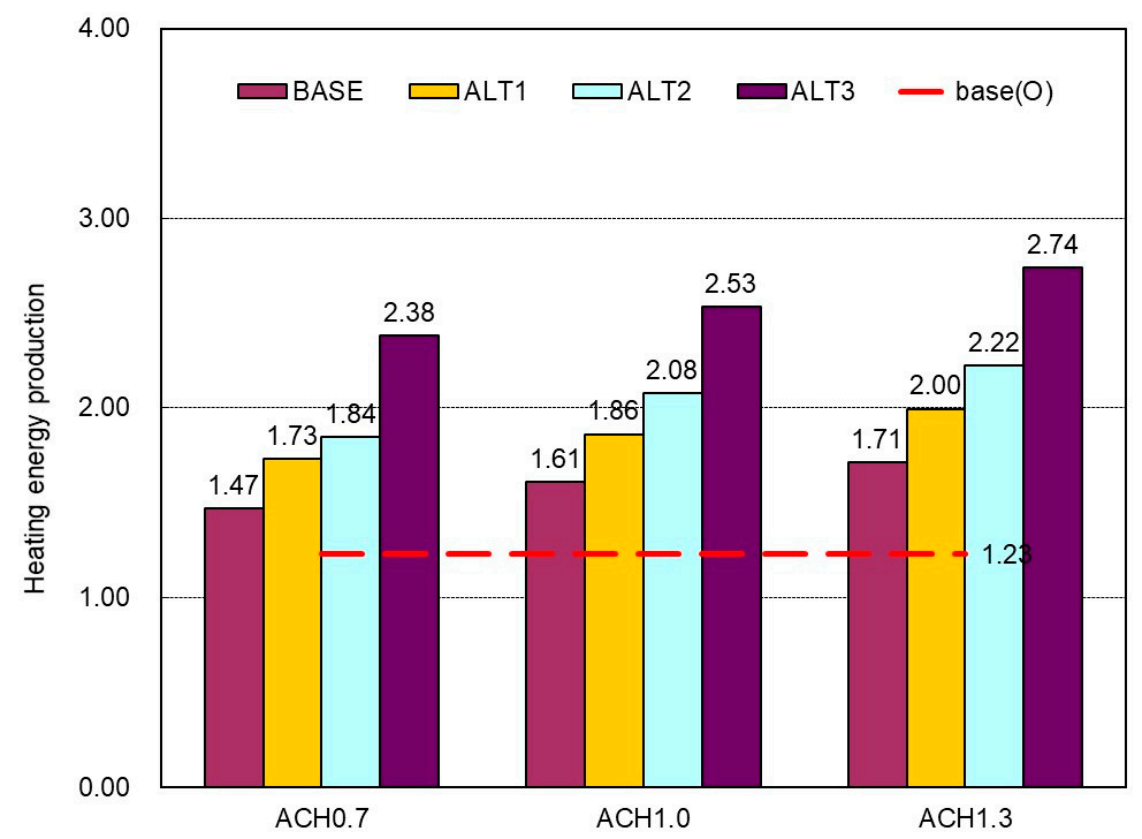

Figure 24. Heating energy production by ALTs.

The heating energy production capacity of the double-skin facade varies depending on the indoor plain type, volume, and insulation performance of the outer skin in the installation side of the 
double-skin facade. Nevertheless, when the capacity exceeds ' 1 ' at least, it is judged that the heating energy generated by the double-skin facade has productivity. According to the analysis, the BASE(O) model with the original OA-based air volume of the double-skin facade used in this study had a heating energy production capacity of 1.23. With the application of an SC and a rise in its height, the heating energy production capacity increased. With an increase in OA-based air volume in each alternative plan, the heat production capacity also went up. In the ALT3 that applied thermal effect to the $\mathrm{SC}$, when the $\mathrm{ACH}$ was 1.3 , the heating energy production capacity was the highest, at 2.74.

In the winter evaluation, the indoor load according to the OA-based air volume and the OA based-heat through the double-skin facade was analyzed in each SC-based alternative plan proposed to improve the heat performance of the double-skin facade. The higher the OA-based air volume was, the higher the double-skin facade-based heat was. The range that began to make the increase in double-skin facade-based heat remain constant was chosen as the appropriate OA-based air volume range (the high and middle levels of solar irradiance: $26,000 \mathrm{CMH}$ or less, the low level of solar irradiance: $15,000 \mathrm{CMH}$ or less). In the chosen OA-based air volume range, as solar irradiance increased, the temperature difference and pressure of the cavity in the upper and lower sides of the double-skin facade increased, and thereby the available heat through the double-skin facade went up. In addition, with the application of an SC and a rise in its height, the available capacity of the solar irradiance of the double-skin facade rose and the heating energy use rate increased. Among the alternative plans, the ALT3 that applied thermal effect had the highest heating energy use rate. In ALT3, when the ACH was 1.3, it was possible to use heating energy about 7.6 times higher than the original performance of the double-skin facade operated with $\mathrm{ACH}$ 0.4. Therefore, the heating energy production capacity in ALT3 was the highest, at 2.74. According to the winter evaluation, with the application of an SC and a rise in its height, the heating energy saving was excellent. When thermal effect was applied to the SC, the heating energy utilization effect of solar irradiance of the double-skin facade was large.

\section{Conclusions}

In order to propose an improved operation plan for a double-skin facade for reducing the indoor load in winter, this study analyzed the thermal phenomenon through the field measurement of the double-skin facade of a real building. In addition, with the use of an energy analysis tool, it verified the effect of the improvement plan. This study came to the following conclusions:

(1) To find the actual state of operation of a double-skin facade in winter, this study measured the target building. As a result, if an appropriate air volume control strategy is applied to reduce the outer skin load and outdoor air load, in terms of the OA use of the preheated air through the double-skin facade, it is possible to save a great deal of energy. Accordingly, this study proposed a solar chimney-based double-skin facade as a passive alternative plan to improve ventilation and energy performance across the seasons.

(2) The solar chimney-based double-skin facade was analyzed in winter. As a result, with the application of a solar chimney and a rise in its height, the available capacity of relatively larger solar heat increased, and therefore the proposed plan had excellent performance in terms of heating energy saving. When thermal effect was applied to the solar chimney, the heating energy use effect of solar irradiance of the double-skin facade was larger. When thermal effect was applied to the three-floor solar chimney, the heating energy use increased to about 7.6 times higher than that of the original performance of the double-skin facade.

Author Contributions: U.-J.S. managed the project and wrote the manuscript. S.-H.K. wrote and edited the manuscript.

Funding: This work was supported by the Korea Institute of Energy Technology Evaluation and Planning (KETEP) and the Ministry of Trade, Industry \& Energy (MOTIE) of the Republic of Korea (No. 20162010104270). 
Acknowledgments: This work was supported by the Korea Institute of Energy Technology Evaluation and Planning (KETEP) and the Ministry of Trade, Industry \& Energy (MOTIE) of the Republic of Korea (No. 20162010104270).

Conflicts of Interest: The authors declare no conflict of interest.

\section{References}

1. Pomponi, F.; Piroozfar, P.A.E.; Southall, R.; Ashton, P.; Farr, E.R.P. Energy performance of Double-Skin Facades in temperate climates: A systematic review and meta-analysis. Renew. Sustain. Energy Rev. 2016, 54, 1525-1536. [CrossRef]

2. Kassai, M. Effectiveness and humidification capacity investigation of liquid-to-air membrane energy exchanger under low heat capacity ratios at winter air conditions. J. Therm. Sci. 2015, 24, 391-397. [CrossRef]

3. Stec, W.J.; Van Paassen, A.H.C.; Maziarz, A. Modelling the double skin facade with plants. Energy Build. 2005, 37, 419-427. [CrossRef]

4. Stec, W.J.; Van Paassen, A.H.C. Symbiosis of the double skin facade with the HVAC system. Energy Build. 2005, 37, 461-469. [CrossRef]

5. Chou, S.K.; Chua, K.J. A study on the effects of double skin facades on the energy management in buildings. Energy Convers. Manag. 2009, 50, 2275-2281. [CrossRef]

6. Xu, L.; Ojima, T. Field experiments on natural energy utilization in a residential house with a double skin facade system. Build. Environ. 2007, 42, 2014-2023. [CrossRef]

7. Gratia, E.; De Herde, A. Is day natural ventilation still possible in office buildings with a double-skin facade? Build. Environ. 2004, 39, 399-409. [CrossRef]

8. Gratia, E.; De Herde, A. Natural cooling strategies efficiency in an office building with a double-skin façade. Energy Build. 2004, 36, 1139-1152. [CrossRef]

9. Gratia, E.; De Herde, A. Natural ventilation in a double-skin façade. Energy Build. 2004, 36, 137-146. [CrossRef]

10. Gratia, E.; De Herde, A. Are energy consumptions decreased with the addition of a double-skin? Energy Build. 2004, 39, 605-619. [CrossRef]

11. Gratia, E.; De Herde, A. Greenhouse effect in double-skin façade. Energy Build. 2004, 39, 199-211. [CrossRef]

12. Gratia, E.; De Herde, A. Guidelines for improving natural daytime ventilation in an office building with a double-skin façade. Sol. Energy 2004, 81, 435-448. [CrossRef]

13. Gratia, E.; De Herde, A. The most efficient position of shading devices in a double-skin façade. Energy Build. 2007, 39, 364-373. [CrossRef]

14. Andelkovic, A.S.; Mujan, I.; Dakic, S. Experimental validation of a EnergyPlus model: Alication of a multi-storey naturally ventilated double skin facade. Energy Build. 2016, 118, 27-36. [CrossRef]

15. Kassai, M. Experimental investigation on the effectiveness of sorption energy recovery wheel in ventilation system. Exp. Heat Transf. 2018, 31, 106-120. [CrossRef]

(C) 2019 by the authors. Licensee MDPI, Basel, Switzerland. This article is an open access article distributed under the terms and conditions of the Creative Commons Attribution (CC BY) license (http://creativecommons.org/licenses/by/4.0/). 